Article

\title{
Supported Bimetallic Catalysts for the Solvent-Free Hydrogenation of Levulinic Acid to $\gamma$-Valerolactone: Effect of Metal Combination (Ni-Cu, Ni-Co, Cu-Co)
}

\author{
Mahlet N. Gebresillase ${ }^{1,+} \mathbb{D}^{\mathbb{D}}$, Reibelle Q. Raguindin ${ }^{1, \dagger}$, Hern Kim $^{1}$ and Jeong Gil Seo ${ }^{2, *}$ \\ 1 Department of Energy Science and Technology, Myongji University, 116 Myongji-ro, Cheoin-gu, Yongin-si, \\ Gyeonggido 17058, Korea; mahletnigus@gmail.com (M.N.G.); rqraguindin@gmail.com (R.Q.R.); \\ hernkim@mju.ac.kr (H.K.) \\ 2 Department of Chemical Engineering, Hanyang University, 222 Wangsimni-ro, \\ Seongdong-gu, Seoul 04763, Korea \\ * Correspondence: jgseo@hanyang.ac.kr; Tel.: +82-2-2220-0520 \\ + These authors contributed equally to this work.
}

Received: 26 October 2020; Accepted: 19 November 2020; Published: 21 November 2020

check for updates

\begin{abstract}
GVL) is an important value-added chemical with potential applications as a fuel additive, a precursor for valuable chemicals, and polymer synthesis. Herein, different monometallic and bimetallic catalysts supported on $\gamma-\mathrm{Al}_{2} \mathrm{O}_{3}$ nanofibers $(\mathrm{Ni}, \mathrm{Cu}, \mathrm{Co}, \mathrm{Ni}-\mathrm{Cu}, \mathrm{Ni}-\mathrm{Co}, \mathrm{Cu}-\mathrm{Co})$ were prepared by the incipient wetness impregnation method and employed in the solvent-free hydrogenation of levulinic acid (LA) to GVL. The influence of metal loading, metal combination, and ratio on the activity and selectivity of the catalysts was investigated. XRD, SEM-EDS, TEM, $\mathrm{H}_{2}$-TPR, XPS, $\mathrm{NH}_{3}$-TPD, and $\mathrm{N}_{2}$ adsorption were used to examine the structure and properties of the catalysts. In this study, GVL synthesis involves the single-step dehydration of LA to an intermediate, followed by hydrogenation of the intermediate to GVL. Ni-based catalysts were found to be highly active for the reaction. [2:1] Ni-Cu/ $\mathrm{Al}_{2} \mathrm{O}_{3}$ catalyst showed $100.0 \%$ conversion of LA with $>99.0 \%$ selectivity to GVL, whereas [2:1] Ni-Co/ $\mathrm{Al}_{2} \mathrm{O}_{3}$ yielded $100.0 \%$ conversion of LA with $83.0 \%$ selectivity to GVL. Moreover, reaction parameters such as temperature, $\mathrm{H}_{2}$ pressure, time, and catalyst loading were optimized to obtain the maximum GVL yield. The solvent-free hydrogenation process described in this study propels the future industrial production of GVL from LA.
\end{abstract}

Keywords: hydrogenation; alumina nanofiber; bimetallic catalysts; levulinic acid; $\gamma$-valerolactone

\section{Introduction}

Due to the concomitant increase of the global consumption of fossil fuels and the rapid depletion of its reserves, research attention has shifted to the investigation and development of sustainable alternatives for fossil fuels as our primary energy source [1]. Lignocellulosic biomass is considered to be one of the most promising replacements of fossil fuels since it is a highly renewable, naturally abundant, carbon-neutral energy source [2]. Levulinic acid (LA), a five-carbon molecule that can be produced from both the C5 and C6 sugars of the lignocellulose, was recognized by the US Department of Energy as one of the top 10 biomass-derived compounds that can potentially replace fossil fuels [3]. A broad spectrum of value-added chemicals can be derived from LA, including $\gamma$-Valerolactone (GVL) [4]. GVL can be synthesized from the hydrogenation of LA, and it offers a tremendous number of applications as a food ingredient, green solvent, fuel additive, and a platform chemical for the production of consumer goods [5,6]. Considering the accessibility of LA as a feedstock and the potential industrial applications of GVL, the hydrogenation of LA to GVL was found to be a promising pathway in biomass conversion reactions. As represented by Scheme 1, GVL can be synthesized from two reaction 
pathways, containing hydrogenation and dehydration steps. Thus, a catalyst with well-balanced metal sites for hydrogenation and acidic sites for dehydration is necessary. The conversion of LA to GVL can proceed via LA's dehydration to angelica lactone (AL), followed by its hydrogenation to GVL. It can also be facilitated by the hydrogenation of the ketone functionality of LA, thereby forming 4-hydroxypentanoic acid (4-HPA), followed by intramolecular esterification/ring closure to GVL [7] Several catalytic technologies, such as the exploitation of a different nature of catalysts, solvents, and hydrogen donors, have been investigated for the transformation of LA to GVL. This reaction was also reported to proceed under a wide range of reaction conditions as mild as room temperature and at a pressure as high as 50 bar. Noble metal-based catalysts, particularly ruthenium $(\mathrm{Ru}),[7,8]$ platinum (Pt) $[9,10]$, and palladium (Pd)-based [11,12] were the most explored group, owing to their high activity in carbonyl hydrogenation. However, the expensive cost and limited supply of these types of materials can bound their industrial application. For this reason, transition-metal-based catalysts have attracted the interest of researchers for the synthesis of GVL since they are of lower cost, more environmentally sustainable, and more widely available. For these types of catalysts, nickel $(\mathrm{Ni})$ and copper $(\mathrm{Cu})$ were the most studied metals. Previous studies have suggested that the synergistic effect of these metals enhanced catalytic activity. The hydrotalcite-derived catalyst $\mathrm{Cu} / \mathrm{Ni} / \mathrm{Mg} / \mathrm{Al}$, with a $0.75 / 0.5 / 1 / 1$ molar ratio of metal cations, has achieved a complete conversion of LA toward GVL at $140{ }^{\circ} \mathrm{C}, 3 \mathrm{~h}$, and $30 \mathrm{bar}$ $\mathrm{H}_{2}$ pressure in 1,4-dioxane. Its activity was attributed to the combined effort of $\mathrm{Ni}$ and $\mathrm{Cu}$, wherein $\mathrm{Cu}$ is responsible for LA conversion and $\mathrm{Ni}$ improved the selectivity toward GVL formation [13]. A study by Obregon et al. also reported the use of commercial $\mathrm{Al}_{2} \mathrm{O}_{3}$-supported monometallic ( $\mathrm{Ni}$ and $\mathrm{Cu}$ ) and bimetallic (Ni-Cu) catalysts for this reaction. A 100.0\% LA conversion with a 96.0\% GVL yield was obtained at $250^{\circ} \mathrm{C}, 65$ bar $\mathrm{H}_{2}$ pressure, and a $2 \mathrm{~h}$ reaction time. The catalytic performance of the Ni-Cu bimetallic catalysts was ascribed to the coexistence of the two metals and the inhibition of by-product formation and carbon deposition with the incorporation of $\mathrm{Cu}$ to Ni [14]. Catalysts concerning cobalt (Co) have recently been shown to exhibit activity for the hydrogenation of LA to GVL. It was suggested that the hydrogenation activity of these cobalt-based catalysts was probably due to the slight amount of surface metallic Co species formed during the reductive catalytic reaction [15]. Moreover, the strong metal-support interaction exhibited by $\mathrm{Co}$ and $\mathrm{Al}$ species has stabilized the Co particles and has prevented their leaching and sintering [16]. All the monometallic catalysts based on $\mathrm{Ni}, \mathrm{Cu}$, and $\mathrm{Co}$ were reported to be active in this reaction with varying LA conversions and GVL yields achieved. To the best of our knowledge, the effect of metal combinations in the solvent-free hydrogenation of LA to GVL has not been studied yet.

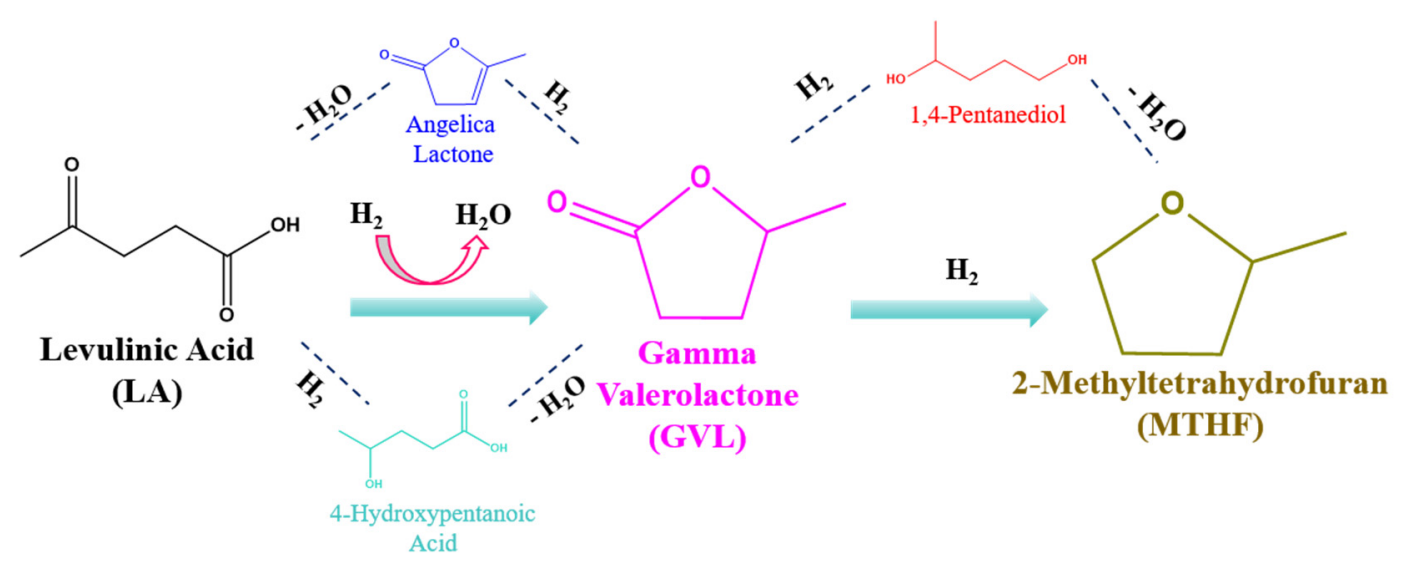

Scheme 1. Reaction pathway for the conversion of LA to GVL.

In this work, we prepared $\gamma-\mathrm{Al}_{2} \mathrm{O}_{3}$ fiber-supported bimetallic $(\mathrm{Ni}-\mathrm{Cu}, \mathrm{Ni}-\mathrm{Co}, \mathrm{Cu}-\mathrm{Co})$ catalysts by incipient wetness impregnation for the transformation of LA to GVL. It was demonstrated that the alumina support provided additional Lewis acid sites by the strong metal-support interaction resulting 
from the reaction between metal precursor and $\mathrm{OH}$ group on the surface of the nanofiber. Reactions were conducted over monometallic catalysts and bimetallic catalysts with [1:1], [2:1], and [1:2] Ni/Cu, Ni/Co, and $\mathrm{Co} / \mathrm{Cu}$ ratios. The conversion of LA and the selectivity to GVL in the solvent-free hydrogenation was enhanced by adjusting the metal and acid sites on the surface of the bimetallic catalysts. [2:1] Ni-Cu/ $\mathrm{Al}_{2} \mathrm{O}_{3},[2: 1] \mathrm{Ni}-\mathrm{Co} / \mathrm{Al}_{2} \mathrm{O}_{3}$, and [2:1] $\mathrm{Co}-\mathrm{Cu} / \mathrm{Al}_{2} \mathrm{O}_{3}$ yielded $>99.0 \%, \sim 83.0 \%$, and $\sim 65.0 \%$ GVL, respectively. The influence of reaction parameters, such as $\mathrm{H}_{2}$ pressure, temperature, and time was also studied. Several characterization techniques, X-ray diffraction (XRD), X-ray photoelectron spectroscopy (XPS), transmission electron microscopy (TEM), ammonia temperature-programmed desorption ( $\left.\mathrm{NH}_{3}-\mathrm{TPD}\right)$, and hydrogen temperature-programmed reduction $\left(\mathrm{H}_{2}-\mathrm{TPR}\right)$, were employed to assess the relationship between the catalyst's chemical and physical properties and its activity.

\section{Results and Discussion}

\subsection{Catalyst Characterization}

$\mathrm{N}_{2}$ adsorption-desorption isotherms and pore size distributions performed to ascertain the structure of the catalysts are presented in Figure 1. All the isotherms obtained for the catalysts display a type IV isotherm with $\mathrm{H} 3$ hysteresis loops. The specific surface area of catalysts was calculated by the Brunauer-Emmett-Teller (BET) method based on the adsorption data in the relative pressure range of $0.05-0.25$. Pore volume was evaluated by the adsorption quantities at a relative pressure of 0.99 . Mesopore size distribution was calculated from the desorption branch by the Barrett-Joyner-Halenda $(\mathrm{BJH})$ method. These isotherms, together with the pore size analysis of all catalysts, suggest that they are mesoporous in nature. The higher surface area of the $\gamma-\mathrm{Al}_{2} \mathrm{O}_{3}$ nanofiber support $\left(259.0 \mathrm{~m}^{2} / \mathrm{g}\right) \mathrm{can}$ be attributed to the arbitrary arrangement of the nanofibers, resulting in a well-established porous structure. After the impregnation of active metals, the surface area decreased due to pore blockage, indicating that the metals were effectively deposited. The significant loss of surface area for the monometallic Ni catalyst compared to all the synthesized catalysts, coupled with the $>70.0 \%$ pore volume loss, may suggest that $\mathrm{Ni}$ deposited within the pores of the $\gamma-\mathrm{Al}_{2} \mathrm{O}_{3}$ nanofiber. Monometallic $\mathrm{Cu}$ and $\mathrm{Co}$ showed a $46.0 \%$ and $52.0 \%$ pore volume loss with increased pore diameter, which may indicate the $\mathrm{Cu}$ deposit on the surface of the $\gamma-\mathrm{Al}_{2} \mathrm{O}_{3}$ nanofiber. A similar phenomenon was observed in previous studies [14]. For Ni-based catalysts, the surface area and pore volume improved with the addition of both $\mathrm{Cu}$ and $\mathrm{Co}$, which can be a result of improved metal dispersion.

a.

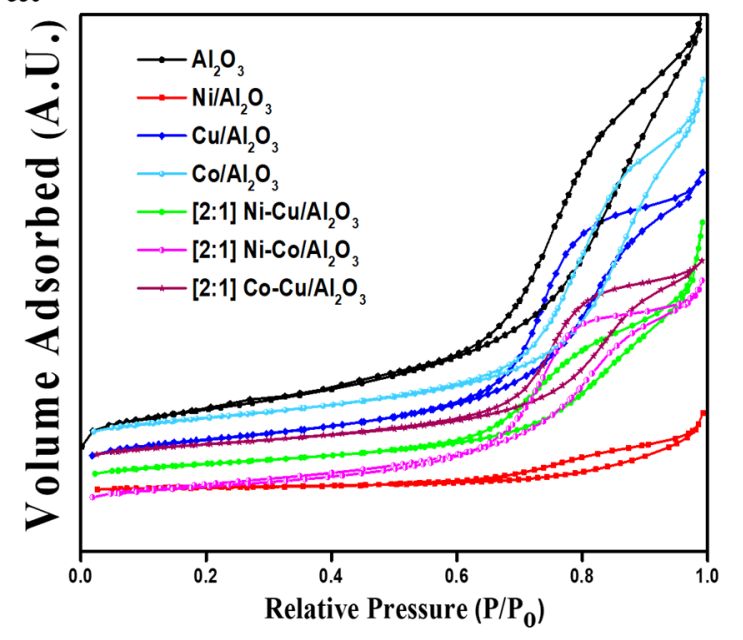

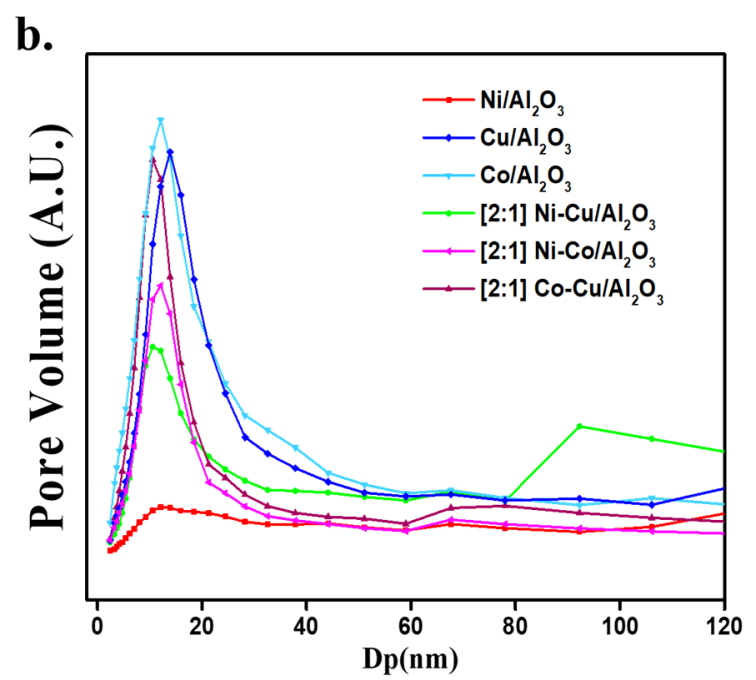

Figure 1. $\mathrm{N}_{2}$ adsorption-desorption isotherms (a) and Barrett-Joyner-Halenda (BJH) pore size distribution (b) of the monometallic and bimetallic catalysts. 
The textural properties of the monometallic catalysts and catalysts with [2:1] $\mathrm{M}_{1} / \mathrm{M}_{2}$ are summarized in Table 1. The textural properties of catalysts with other ratios are reviewed in Table S2. The experimental active metal contents $(\mathrm{Ni}, \mathrm{Co}, \mathrm{Cu})$ in both monometallic and bimetallic catalysts were determined by ICP-OES, and the results are summarized in Table 1 . The crystallite sizes of the catalysts were calculated using the Scherrer equation based on the peak with the highest intensity. The total metal content and the metal ratio of the catalysts were found to be comparable with the given metal contents of catalysts.

Table 1. Elemental and textural characterization of the reduced catalysts.

\begin{tabular}{|c|c|c|c|c|c|c|c|c|c|}
\hline Catalysts & $\begin{array}{c}\mathrm{Ni} \\
(w \mathrm{t} . \%)^{\mathrm{a}}\end{array}$ & $\begin{array}{c}\mathrm{Cu} \\
(w \mathrm{t} . \%)^{\mathrm{a}}\end{array}$ & $\begin{array}{c}\text { Co } \\
(w t . \%)^{a}\end{array}$ & $\begin{array}{l}\text { Total } \\
\text { wt. } \%\end{array}$ & $\mathbf{M}_{1} / \mathbf{M}_{2}$ & $\begin{array}{c}S_{B E T} \\
\left(\mathrm{~m}^{2} / g\right)\end{array}$ & $\begin{array}{l}\text { Pore Volume } \\
\left(\mathrm{cm}^{3} / \mathrm{g}\right)^{\mathrm{c}}\end{array}$ & $\begin{array}{l}\text { Pore Diameter } \\
(\mathrm{nm})^{c}\end{array}$ & $\begin{array}{l}\text { Crystallize } \\
\text { size }(n m)^{d}\end{array}$ \\
\hline $\mathrm{Al}_{2} \mathrm{O}_{3}$ & 0.0 & 0.0 & 0.0 & 0.0 & 0.0 & 259.0 & 0.99 & 17.6 & 24.6 \\
\hline $\mathrm{Ni} / \mathrm{Al}_{2} \mathrm{O}_{3}$ & 37.3 & 0.0 & 0.0 & 37.3 & 0.0 & 129.6 & 0.29 & 7.4 & 41.7 \\
\hline $\mathrm{Cu} / \mathrm{Al}_{2} \mathrm{O}_{3}$ & 0.0 & 31.0 & 0.0 & 31.0 & 0.0 & 147.0 & 0.53 & 14.2 & 82.8 \\
\hline $\mathrm{Co} / \mathrm{Al}_{2} \mathrm{O}_{3}$ & 0.0 & 0.0 & 32.3 & 34.1 & 0.0 & 152.3 & 0.48 & 13.9 & 32.8 \\
\hline $\begin{array}{c}{[2: 1]} \\
\mathrm{Ni}-\mathrm{Cu} / \mathrm{Al}_{2} \mathrm{O}_{3}\end{array}$ & 20.9 & 12.1 & 0.0 & 33.0 & 1.72 & 144.0 & 0.38 & 11.8 & 58.9 \\
\hline $\begin{array}{c}{[2: 1]} \\
\mathrm{Ni}-\mathrm{Co} / \mathrm{Al}_{2} \mathrm{O}_{3}\end{array}$ & 21.4 & 0.0 & 11.3 & 32.7 & 1.89 & 159.4 & 0.45 & 12.0 & 36.3 \\
\hline $\begin{array}{c}{[2: 1]} \\
\mathrm{Co}-\mathrm{Cu} / \mathrm{Al}_{2} \mathrm{O}_{3}\end{array}$ & 0.0 & 23.1 & 13.7 & 36.8 & 1.69 & 162.1 & 0.41 & 13.3 & 63.1 \\
\hline
\end{tabular}

${ }^{a}$ Determined by inductively coupled plasma optical emission spectrometry (ICP-OES). ${ }^{b}$ Brunauer-Emmett-Teller (BET) surface area calculated from $\mathrm{N}_{2}$ adsorption-desorption isotherms using BET. ${ }^{c}$ Pore volume and pore diameter calculated from $\mathrm{N}_{2}$ adsorption-desorption isotherms using BJH. ${ }^{\mathrm{d}}$ Crystallite size was calculated using the Scherrer equation.

The XRD diagrams of the reduced catalysts are presented in Figure 2 and Figure S1. The characteristic peaks of the nickel phase were at $2 \theta=44.6,51.7$ and 76.3 for $\mathrm{Ni} / \mathrm{Al}_{2} \mathrm{O}_{3}$, whereas a copper phase at $2 \theta=43.5,50.5$ and 74.5 and a cobalt phase at $2 \theta=44.3,51.4$, and 74.3 were identified for $\mathrm{Cu} / \mathrm{Al}_{2} \mathrm{O}_{3}$ and $\mathrm{Co} / \mathrm{Al}_{2} \mathrm{O}_{3}$, respectively [17]. The $\mathrm{Co} / \mathrm{Al}_{2} \mathrm{O}_{3}$ catalyst showed a smaller diffraction peak due to the superior dispersion of the Co species on the $\gamma-\mathrm{Al}_{2} \mathrm{O}_{3}$ nanofibers. The sharper diffraction peaks observed for Ni diffraction peaks in the monometallic Ni compared to the monometallic $\mathrm{Cu}$ and monometallic Co catalyst indicate that $\mathrm{Ni}$ particles were significantly larger because of metal aggregation. The existence of the $\mathrm{Ni}-\mathrm{Cu}, \mathrm{Ni}-\mathrm{Co}$, and $\mathrm{Co}-\mathrm{Cu}$ mixed-species was also confirmed for the reduced bimetallic catalysts. Although the XRD patterns of the bimetallic catalysts appear similar, a closer look at the diffraction peaks of the catalysts shows a shift for the peak linked to metallic Ni to lower angle values for Ni-Co-based $(2 \theta=44.3)$ and Ni-Cu-based $(2 \theta=44.2)$ catalysts. This slight peak shift indicated the $\mathrm{Co}$ and $\mathrm{Cu}$ integration into the $\mathrm{Ni}$ crystal structure. In the case of $\mathrm{Co}-\mathrm{Cu} / \mathrm{Al}_{2} \mathrm{O}_{3}$, the characteristic peak of metallic $\mathrm{Co}$ has shifted to a lower angle, indicating the formation of a $\mathrm{Co}-\mathrm{Cu}$ alloy. The intensity of nickel peaks decreased for $\mathrm{Ni}-\mathrm{Cu} / \mathrm{Al}_{2} \mathrm{O}_{3}$ and $\mathrm{Ni}-\mathrm{Co} / \mathrm{Al}_{2} \mathrm{O}_{3}$ catalysts with different metal ratios in the order [2:1] > [1:1] > [1:2], as can be seen in Figure S1, which can be attributed to the improved metal dispersion when compared to the monometallic $\mathrm{Ni} / \mathrm{Al}_{2} \mathrm{O}_{3}$ catalyst. Thus, further characterization was performed for the monometallic catalysts and the bimetallic catalysts with a [2:1] metal ratio. Similar results can be seen from the works of Daniel et al. and Mahdi et al. [18,19]. 


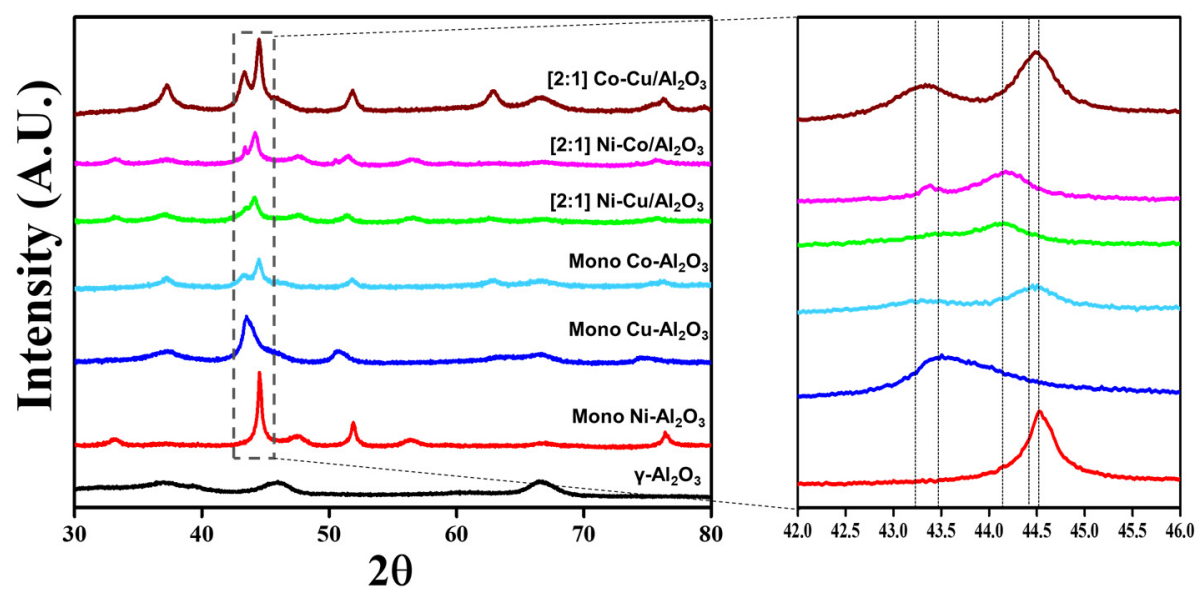

Figure 2. XRD patterns of the reduced monometallic and bimetallic catalysts.

The reducibility of the selected catalysts, together with the active metal-support interaction, was assessed by the $\mathrm{H}_{2}$-TPR analysis, as shown in Figure 3. Ni/ $\mathrm{Al}_{2} \mathrm{O}_{3}, \mathrm{Cu} / \mathrm{Al}_{2} \mathrm{O}_{3}$, and $\mathrm{Co} / \mathrm{Al}_{2} \mathrm{O}_{3}$ exhibited reduction peaks at low- and high-temperature ranges. For monometallic Ni catalyst, the two peaks are at $180^{\circ} \mathrm{C}$ and $520^{\circ} \mathrm{C}$. For the monometallic $\mathrm{Cu}$ catalyst, the peaks are at $200^{\circ} \mathrm{C}$ and $520^{\circ} \mathrm{C}$. For the monometallic Co catalyst, the peaks are at $220^{\circ} \mathrm{C}$ and $520^{\circ} \mathrm{C}$. The low-temperature peaks are allocated to the reduction of metal oxide with no interaction with $\gamma-\mathrm{Al}_{2} \mathrm{O}_{3}$ nanofibers, whereas the high-temperature peaks are for the reduction of spinel $\mathrm{NiAl}_{2} \mathrm{O}_{4}, \mathrm{CuAl}_{2} \mathrm{O}_{4}$, and $\mathrm{CoAl}_{2} \mathrm{O}_{4}$. The significant high-temperature peak of the monometallic $\mathrm{Ni}$ catalyst may suggest $\mathrm{NiO}$ species were embedded further inside the $\gamma-\mathrm{Al}_{2} \mathrm{O}_{3}$ nanofibers, supporting the observation from the $\mathrm{N}_{2}$ adsorption-desorption data. [2:1] Ni-Cu/Al ${ }_{2} \mathrm{O}_{3}$ and [2:1] Ni-Co/ $\mathrm{Al}_{2} \mathrm{O}_{3}$ catalysts show two peaks positioned below $300{ }^{\circ} \mathrm{C}$ and $550{ }^{\circ} \mathrm{C}$ with a shoulder peak at $600{ }^{\circ} \mathrm{C}$. In $[2: 1] \mathrm{Ni}-\mathrm{Cu} / \mathrm{Al}_{2} \mathrm{O}_{3}$, the peak at $200-300{ }^{\circ} \mathrm{C}$ relates to the reduction of support-free $\mathrm{NiO}$. The peak at $500{ }^{\circ} \mathrm{C}$ can be allocated to the reduction of crystal $\mathrm{NiO}$ species, whereas the high-temperature shoulder peak at a range of $550-600{ }^{\circ} \mathrm{C}$ relates to the reduction of $\mathrm{NiAl}_{2} \mathrm{O}_{4}$ from the robust metal-support interaction. The peak around $250{ }^{\circ} \mathrm{C}$ for [2:1] $\mathrm{Ni}-\mathrm{Co} / \mathrm{Al}_{2} \mathrm{O}_{3}$ describes the reduction of $\mathrm{NiO}$ with no interaction with support. The peak above $500{ }^{\circ} \mathrm{C}$ can be attributed to the reduction of $\mathrm{CoO}$ species and tetrahedral $\mathrm{Ni}^{2+}$ located on $\gamma-\mathrm{Al}_{2} \mathrm{O}_{3}$ with a metal-support interaction [18,20]. In the TPR profile of [2:1] $\mathrm{Ni}-\mathrm{Cu} / \mathrm{Al}_{2} \mathrm{O}_{3}$ and [2:1] $\mathrm{Co}-\mathrm{Cu} / \mathrm{Al}_{2} \mathrm{O}_{3}$ catalysts, the low-temperature reduction peak at around $150{ }^{\circ} \mathrm{C}$ is correlated with the reduction of $\mathrm{CuO}$ species. The presence of $\mathrm{Cu}$ enhances the reducibility of the $\mathrm{NiO}$ and $\mathrm{CoO}$ by behaving as an activation site for hydrogen molecules, which, in turn, enhances the reduction of $\mathrm{NiO}$ and $\mathrm{CoO}[17,21,22]$. The decreased intensity of the shoulder peak for bimetallic catalysts at high temperature indicates better metal dispersion. The $\mathrm{H}_{2}$-TPR results show that the intensity of the high-temperature peak associated with the spinel $\mathrm{MAl}_{2} \mathrm{O}_{4}$ decreased from [2:1] Ni-Cu/Al $\mathrm{O}_{3}$ to $[2: 1] \mathrm{Ni}-\mathrm{Co} / \mathrm{Al}_{2} \mathrm{O}_{3}$, followed by [2:1] $\mathrm{Co}-\mathrm{Cu} / \mathrm{Al}_{2} \mathrm{O}_{3}$, confirming that the bimetallic catalysts compared to the monometallic catalysts retained more reduced metallic sites similar to the previously reported studies $[14,23]$. 


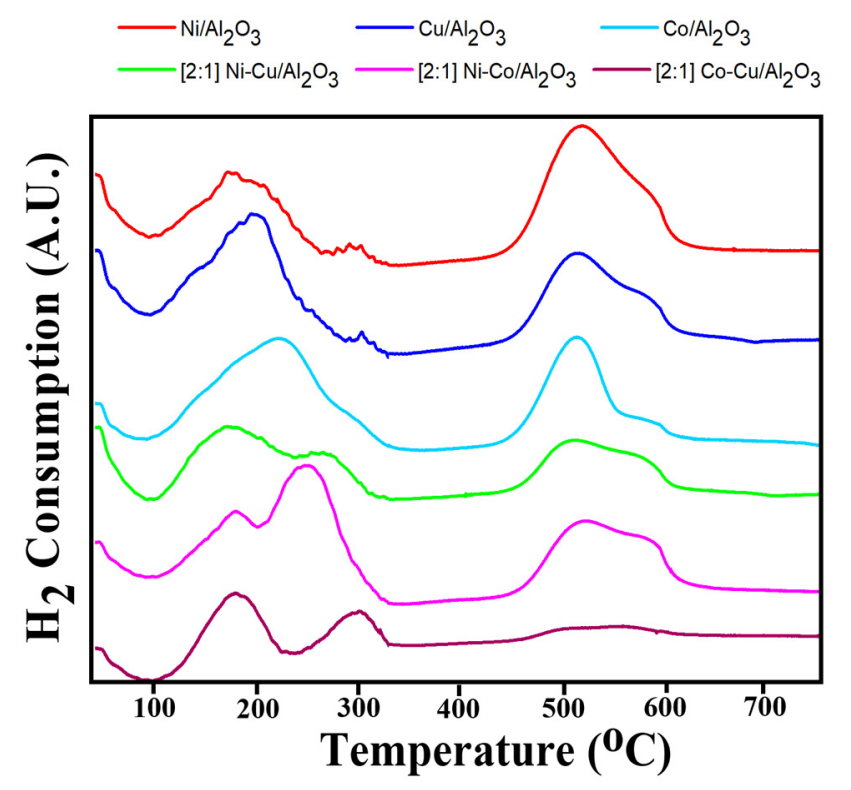

Figure 3. TPR patterns of calcined monometallic and bimetallic catalysts.

The SEM images of the selected catalysts are shown in Figure 4. The SEM images exhibited similar morphologies with the bare $\gamma-\mathrm{Al}_{2} \mathrm{O}_{3}$ nanofibers. When compared with the monometallic $\mathrm{Ni} / \mathrm{Al}_{2} \mathrm{O}_{3}$ catalyst, the [2:1] bimetallic catalysts showed smaller particle sizes, revealing that the consistency of metal particle distribution was improved with the addition of $\mathrm{Cu}$ and $\mathrm{Co}$ for the Ni-based catalysts. The incorporation of $\mathrm{Cu}$ and Co could inhibit agglomeration, boosting the dispersion of the nickel species on the $\gamma-\mathrm{Al}_{2} \mathrm{O}_{3}$ nanofibers. The elemental mapping of the catalyst showed well-dispersed metal particles over the $\mathrm{Al}_{2} \mathrm{O}_{3}$ support for all the catalysts except $\mathrm{Ni} / \mathrm{Al}_{2} \mathrm{O}_{3}$, in good agreement with the XRD results. The mapping in the case of $\mathrm{Ni} / \mathrm{Al}_{2} \mathrm{O}_{3}$ shows a more pronounced Ni presence on the surface of the $\gamma-\mathrm{Al}_{2} \mathrm{O}_{3}$ nanofibers, suggesting agglomeration of the Ni particles. The metal wt.\% of catalysts obtained from the EDX analysis was analogous with the values acquired from the ICP-OES and the theoretical value.

The TEM images in Figure 5 show dark particles, which can be attributed to the successful impregnation of metals over the support. All the bimetallic catalysts showed excellent interaction between metals and support with good dispersion. It is possible to note that the active metal is unequally dispersed on the surface of the $\mathrm{Ni} / \mathrm{Al}_{2} \mathrm{O}_{3}$ catalyst, showing a formation of aggregates with altered morphology. With the addition of a second metal ( $\mathrm{Cu}$ and $\mathrm{Co})$ to the monometallic Ni catalyst, the dispersion of the active metal species was enhanced. Particularly, for $\mathrm{Ni}-\mathrm{Co} / \mathrm{Al}_{2} \mathrm{O}_{3}$ catalysts, a uniform distribution of smaller metallic particles can be seen when compared to $\mathrm{Ni}-\mathrm{Cu} / \mathrm{Al}{ }_{2} \mathrm{O}_{3}$. This result is in line with the XRD data. A more prominent particle distribution can be seen for the $\mathrm{Co}-\mathrm{Cu} / \mathrm{Al}_{2} \mathrm{O}_{3}$ catalyst, indicating that Ni-based catalysts are more prone to the formation of aggregates. A closer look is shown in Figure S2. 


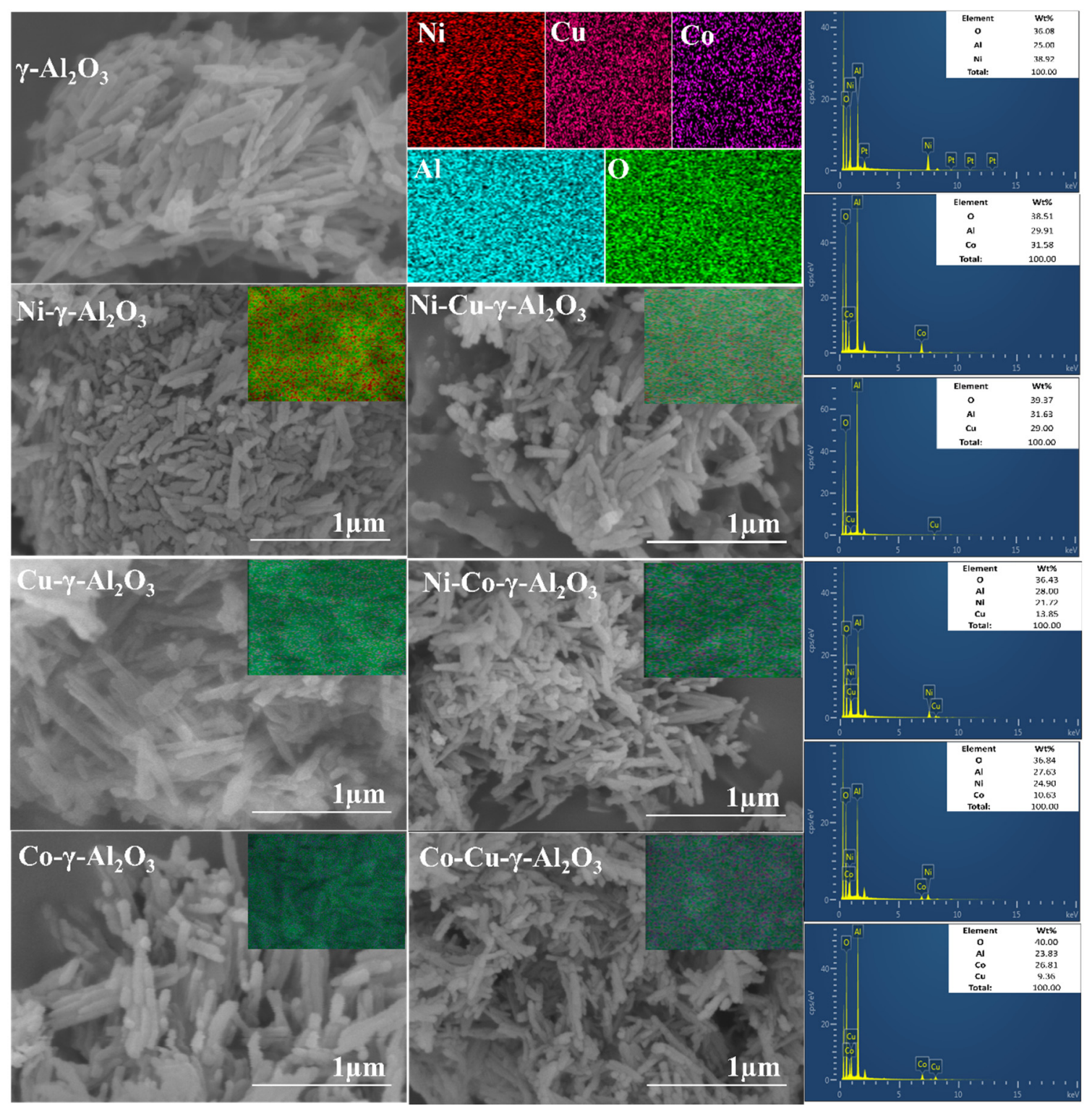

Figure 4. SEM images, elemental mapping and EDX patterns of the monometallic and bimetallic catalysts.

XPS analysis was conducted for the selected catalysts after reduction to investigate the effect of the addition of a second metal on the surface properties of the monometallic catalysts. The XPS results of the Ni 2p, Cu 2p, and Co $2 p$ spectra are presented in Figure 6. Based on the deconvolution of Ni 2p spectra, the binding energies at $852.5 \mathrm{eV}$ in the $\mathrm{Ni} 2 \mathrm{p} 3 / 2$ spectra of the reduced $\mathrm{Ni} / \mathrm{Al}_{2} \mathrm{O}_{3}$ catalyst is assigned to the metallic $\mathrm{Ni}$. The XPS spectra of $\mathrm{Ni} / \mathrm{Al}_{2} \mathrm{O}_{3}$ also presented two peaks in the $\mathrm{Ni} 2 \mathrm{p} 3 / 2$ and $\mathrm{Ni} 2 \mathrm{p} 1 / 2$ spectra at about $855.4 \mathrm{eV}$ and $873.8 \mathrm{eV}$ with corresponding satellite peaks at $862.7 \mathrm{eV}$ and $880 \mathrm{eV}$, respectively, which are assigned the $\mathrm{Ni}^{2+}$ species [23]. $\mathrm{Ni}^{0}$ binding energies in the $\mathrm{Ni} 2 \mathrm{p} 3 / 2$ spectra in the bimetallic catalysts $\mathrm{Ni}-\mathrm{Cu} / \mathrm{Al}_{2} \mathrm{O}_{3}$ and $\mathrm{Ni}-\mathrm{Co} / \mathrm{Al}_{2} \mathrm{O}_{3}$ are $853.3 \mathrm{eV}$ and $853.7 \mathrm{eV}$, respectively. 

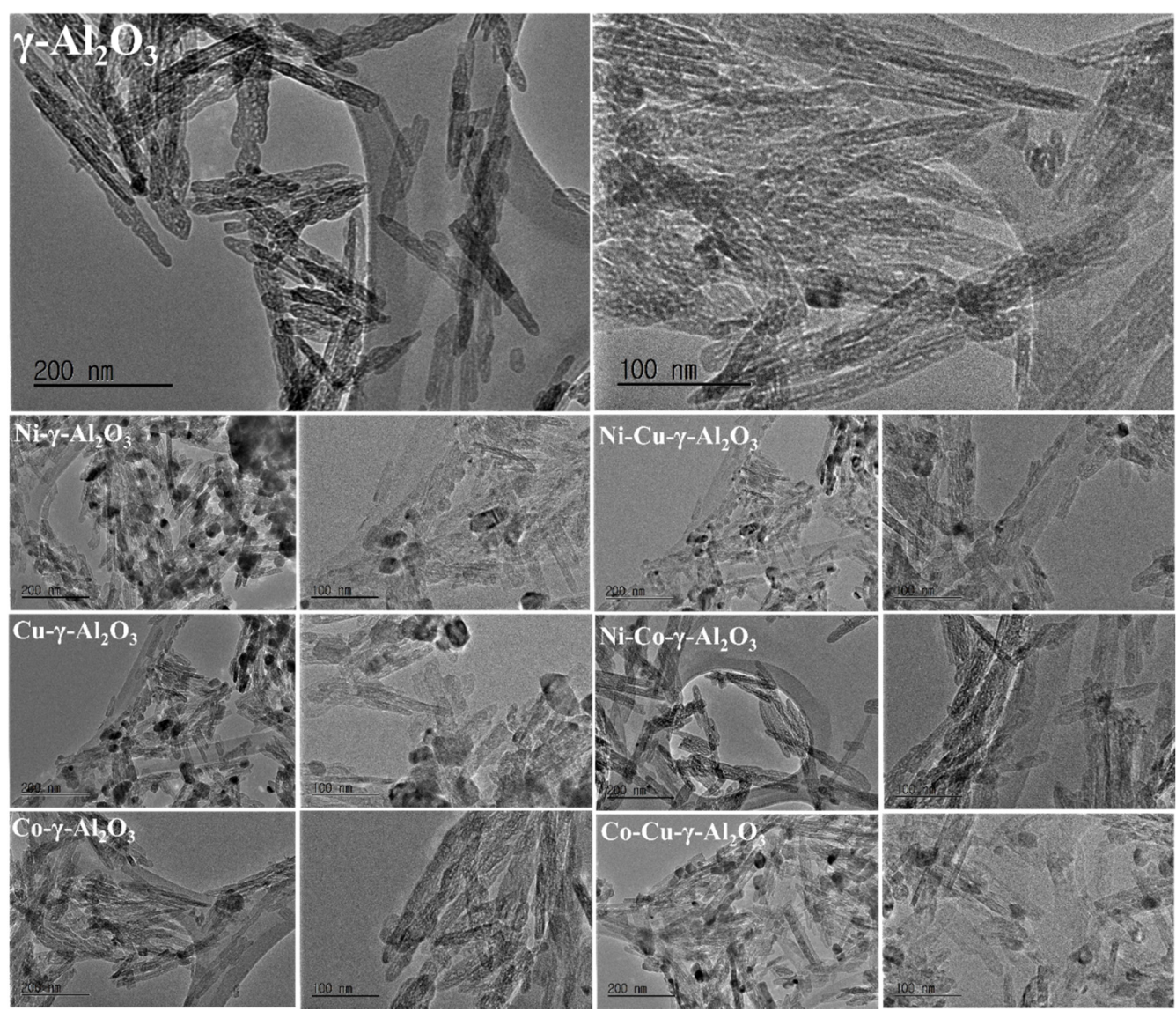

Figure 5. TEM images of monometallic and bimetallic catalysts.

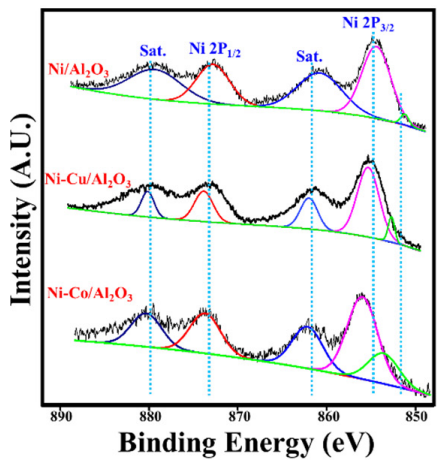

(a)

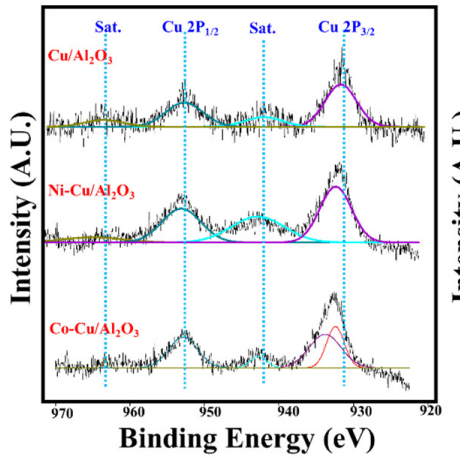

(b)

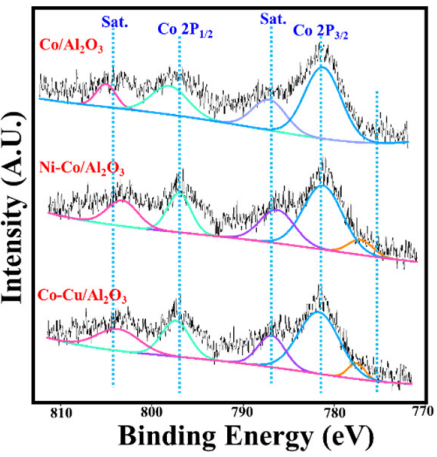

(c)

Figure 6. Deconvoluted XPS patterns (a). Ni 2p (b). Cu 2p (c). Co $2 p$ of reduced monometallic and bimetallic catalysts.

The peaks attributed to the $\mathrm{Ni}^{2+} \mathrm{Ni} 2 \mathrm{p} 3 / 2$ and $\mathrm{Ni} 2 \mathrm{p} 1 / 2$ spectra were also present for the bimetallic catalysts at $856.3 \mathrm{eV}$ and $856.7 \mathrm{eV}$ with satellite peaks for $\mathrm{Ni}-\mathrm{Cu} / \mathrm{Al}_{2} \mathrm{O}_{3}$ and $\mathrm{Ni}-\mathrm{Co} / \mathrm{Al}_{2} \mathrm{O}_{3}$, respectively. It is possible to note that all the peaks in the bimetallic catalysts shifted to higher binding energies in comparison with $\mathrm{Ni} / \mathrm{Al}_{2} \mathrm{O}_{3}$ [22]. The results suggest that the addition of second metals improved the reducibility of nickel species and the interaction between nickel particles and $\gamma-\mathrm{Al}_{2} \mathrm{O}_{3}$ nanofiber support, which was also demonstrated in the $\mathrm{H}_{2}$-TPR. The existence of $\mathrm{Cu}^{2+}$ species in the $\mathrm{Cu} / \mathrm{Al}_{2} \mathrm{O}_{3}$ catalysts was confirmed by the $\mathrm{Cu} 2 \mathrm{p}$ spectra. The $\mathrm{Cu} 2 \mathrm{p}$ spectra for $\mathrm{Cu} 2 \mathrm{p} 3 / 2$ and $\mathrm{Cu} 2 \mathrm{p} 1 / 2$ gave 
two main peaks at about $932.6 \mathrm{eV}$ and $953.6 \mathrm{eV}$ with lower satellite peaks at around $943.4 \mathrm{eV}$ and $963.4 \mathrm{eV}$. The binding energies for the Ni-Cu/ $\mathrm{Al}_{2} \mathrm{O}_{3}$ and $\mathrm{Co}-\mathrm{Cu} / \mathrm{Al}_{2} \mathrm{O}_{3}$ catalysts shifted positively, indicating that there are strong electronic interactions between $\mathrm{Ni}-\mathrm{Cu}$ and $\mathrm{Co}-\mathrm{Cu}$ atoms in Ni-Cu/ $\mathrm{A}_{12} \mathrm{O}_{3}$ and $\mathrm{Co}-\mathrm{Cu} / \mathrm{Al}_{2} \mathrm{O}_{3}$, respectively. From the XPS spectra of $\mathrm{Co} 2 \mathrm{p}$, for reduced $\mathrm{Co} / \mathrm{Al}_{2} \mathrm{O}_{3}, \mathrm{Ni}-\mathrm{Co} / \mathrm{Al}_{2} \mathrm{O}_{3}$, and $\mathrm{Co}-\mathrm{Cu} / \mathrm{Al}_{2} \mathrm{O}_{3}$, the binding energies at $781.7 \mathrm{eV}$ and $797.6 \mathrm{eV}$ with corresponding satellite peaks in the Co 2p3/2 and Co 2p1/2 spectra are attributed to the $\mathrm{Co}^{2+}$ and $\mathrm{Co}^{3+}$ species. The weak peak at $777.2 \mathrm{eV}$ in the $\mathrm{Co} 2 \mathrm{p} 3 / 2$ spectra of $\mathrm{Co} / \mathrm{Al}_{2} \mathrm{O}_{3}$ is attributed to the metallic Co shifted to $878.1 \mathrm{eV}$ with increased intensity for $\mathrm{Ni}-\mathrm{Co} / \mathrm{Al}_{2} \mathrm{O}_{3}$ and $\mathrm{Co}-\mathrm{Cu} / \mathrm{Al}_{2} \mathrm{O}_{3}$, indicating that metal species are rich in bimetallic catalysts, as has been presented in previous studies of bimetallic catalysts $[17,22,24]$.

$\mathrm{NH}_{3}$-TPD was performed to ascertain the acidity of the three selected bimetallic catalysts, and the result is presented in Figure 7. The existence of weak and moderate to strong acidic sites was confirmed for all the catalysts by the presence of the three peaks between the temperatures 100 and $350^{\circ} \mathrm{C}, 350$ and $550{ }^{\circ} \mathrm{C}$, and 550 and $900{ }^{\circ} \mathrm{C}$. The intensity of the peaks originating from the $\mathrm{Ni}-\mathrm{Co} / \mathrm{Al}_{2} \mathrm{O}_{3}$ catalysts was higher compared to $\mathrm{Ni}-\mathrm{Cu} / \mathrm{Al}_{2} \mathrm{O}_{3}$, indicating that $\mathrm{Ni}-\mathrm{Co} / \mathrm{Al}_{2} \mathrm{O}_{3}$ retains the highest density of acidic sites among all the catalysts. This might be because of its higher surface area developed from the enhanced metal dispersion, which is advantageous to the accessibility of the acidic sites. Even though the surface area of $\mathrm{Co}-\mathrm{Cu} / \mathrm{Al}_{2} \mathrm{O}_{3}$ is higher than the other bimetallic catalysts, it exhibits the lowest acidity, especially at a higher temperature. This shows that the presence of $\mathrm{Ni}$ in $\mathrm{Ni}-\mathrm{Co} / \mathrm{Al}_{2} \mathrm{O}_{3}$ and $\mathrm{Ni}-\mathrm{Cu} / \mathrm{Al}_{2} \mathrm{O}_{3}$, in addition to the surface area, may significantly contribute to the densities of acidic sites by providing a more prominent metal-support interface. The work reported by Mengran et al. also demonstrated the same conclusions [14,17].

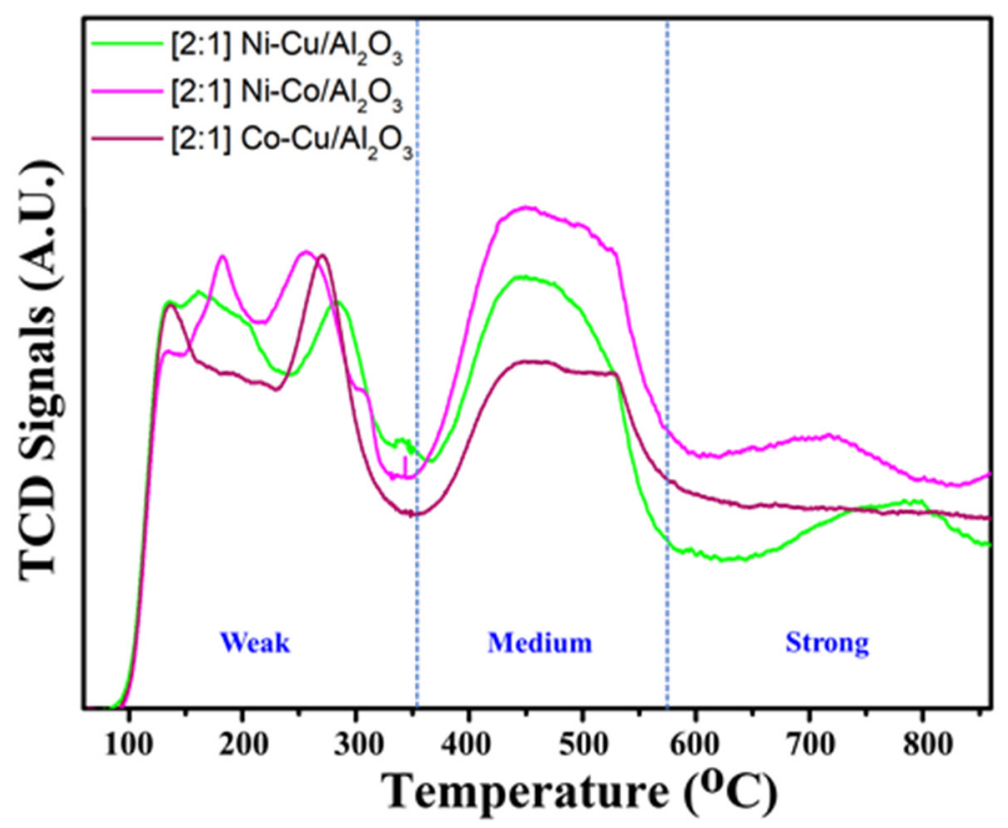

Figure 7. The $\mathrm{NH}_{3}$-TPD patterns of the selected bimetallic catalysts.

\subsection{Catalytic Activity}

To determine the appropriate metal loading for the hydrogenation reaction, [2:1] Ni-Cu/ $\mathrm{Al}_{2} \mathrm{O}_{3}$ catalysts with a 10-50 wt.\% total metal content were synthesized. The results summarized in Table S3 show $35 \mathrm{wt} . \%$ gives the maximum GVL yield; thus, $35 \mathrm{wt} . \%$ was fixed for all the catalysts in this study. The catalytic activity of several monometallic and bimetallic catalysts with varying metal ratios (M1/M2) were successfully synthesized and applied in the solvent-free hydrogenation of LA to GVL. The hydrogenation activity of the catalysts was studied in terms of metal combinations at 
different ratios. The selected catalysts were further tuned by investigating the activities at different reaction parameters.

\subsubsection{Effect of Metal Ratio and Combination}

LA can be converted to GVL via two different pathways, as shown in Scheme 1. The pathway can be via hydrogenation of the carbonyl group in LA, resulting in the formation of the intermediate 4- 4-HPA. Consequent dehydration and esterification result in cyclization, generating GVL or dehydration of LA to AL followed by AL hydrogenation to GVL. In all pathways, the hydrogenation step takes place on the metal catalyst, whereas dehydration and cyclization occur on the acid sites. The 4-HPA pathway of GVL has been shown to kinetically take over at low temperatures [5]. However, the hydrogenation activity of transition metals is low compared to noble metals; therefore, higher temperatures are needed to start the hydrogenation of LA. At high temperatures $\left(\sim 220^{\circ} \mathrm{C}\right)$, LA could be easily dehydrated to $\mathrm{AL}$, suggesting that the AL pathway is responsible for GVL production in this work [25-27].

The Ni/ $\mathrm{Al}_{2} \mathrm{O}_{3}$ catalyst showed a $100.0 \%$ conversion of LA with $75.0 \%$ selectivity to GVL. The final reaction mixture showed $25.0 \%$ selectivity to AL. The result presented in Figure 8 suggests that $\mathrm{Ni} / \mathrm{Al}_{2} \mathrm{O}_{3}$ favors $\mathrm{AL}$, which can be explained by the characteristics of the $\mathrm{Ni} / \mathrm{Al}_{2} \mathrm{O}_{3}$ catalyst observed in the XRD, TPR, and XPS data. $\gamma-\mathrm{Al}_{2} \mathrm{O}_{3}$ has Lewis acid sites with different acid strengths. The reaction between the Ni precursor and $\mathrm{OH}$ group on the surface of the $\gamma-\mathrm{Al}_{2} \mathrm{O}_{3}$ nanofiber results in a strong metal-support interaction, leading to the formation of more $\mathrm{NiAl}_{2} \mathrm{O}_{4}$ with medium to strong Lewis acid sites, decreasing the metallic Ni sites. Because AL is produced by the acid-catalyzed dehydration of $\mathrm{LA}$, and since $\mathrm{Ni} / \mathrm{Al}_{2} \mathrm{O}_{3}$ has more acid sites, $\mathrm{LA}$ is completely converted to $\mathrm{AL}$. In the conversion of $\mathrm{AL}$ to GVL, active metal sites proficient at dissociating the supplied hydrogen and hydrogenating the $\mathrm{C}=\mathrm{C}$ of $\mathrm{AL}$ to obtain GVL are crucial. However, the $\mathrm{Ni} / \mathrm{Al}_{2} \mathrm{O}_{3}$ catalyst does not have enough metal sites to fully convert AL to GVL, resulting only in $75.0 \%$ selectivity to GVL.

To improve product selectivity, the second metals ( $\mathrm{Co}$ or $\mathrm{Cu}$ ) were introduced into the Ni-based catalysts since bimetallic catalysts have a synergistic effect that enhances both metal and acid sites. Compared with monometallic $\mathrm{Ni}$, bimetallic $\mathrm{Ni}-\mathrm{Cu}$ catalysts exhibit much higher selectivity to GVL. The addition of $\mathrm{Cu}$ to the $\mathrm{Ni} / \mathrm{Al}_{2} \mathrm{O}_{3}$ catalyst increases the reducibility of $\mathrm{Ni}$, resulting in the formation of electron-rich $\mathrm{Ni}^{0}$ species, as confirmed by the TPD and XRD data. The amount of metal sites decreased in the order of [1:2] Ni-Cu/ $\mathrm{Al}_{2} \mathrm{O}_{3}>[2: 1] \mathrm{Ni}-\mathrm{Cu} / \mathrm{Al}_{2} \mathrm{O}_{3}>[1: 1] \mathrm{Ni}-\mathrm{Cu} / \mathrm{Al}_{2} \mathrm{O}_{3}$, whereas the acid density decreased in the order of [1:1] Ni-Cu/ $\mathrm{Al}_{2} \mathrm{O}_{3}>[2: 1] \mathrm{Ni}-\mathrm{Cu} / \mathrm{Al}_{2} \mathrm{O}_{3}>$ [1:2] Ni-Cu/Al ${ }_{2} \mathrm{O}_{3}$. Similarly, the selectivity to GVL increased from [1:1] Ni-Cu/Al ${ }_{2} \mathrm{O}_{3}<[2: 1] \mathrm{Ni}-\mathrm{Cu} / \mathrm{Al}_{2} \mathrm{O}_{3}<[1: 2] \mathrm{Ni}-\mathrm{Cu} / \mathrm{Al}_{2} \mathrm{O}_{3}$, proving that the presence of $\mathrm{Cu}$ is essential for the selective production of GVL. A decrease in the conversion of $\mathrm{LA}$ can be noted for the [1:2] $\mathrm{Ni}-\mathrm{Cu} / \mathrm{Al}_{2} \mathrm{O}_{3}$ catalyst, suggesting that not enough acid sites are present for the dehydration of LA. The surface acid sites (cationic $\mathrm{Al}^{3+}$ ) can act as electron acceptors, interacting with LA through electronegative atoms in the LA with lone-pair electrons (carbonyl group, oxygen atom). The partial charge-transfer character of the resulting-O-cation complex makes the lone-pair donor (LA) more electronegative, activating LA for intermolecular nucleophilic attack from the other carbonyl group within LA, resulting in cyclization. Hence, acidic sites on $\mathrm{Ni}-\mathrm{Cu} / \mathrm{Al}_{2} \mathrm{O}_{3}$ catalysts are crucial for the conversion of LA. Thus, the trade-off between metal sites and acid sites for [1:1] Ni-Cu/Al ${ }_{2} \mathrm{O}_{3}$ and [1:2] Ni-Cu/Al ${ }_{2} \mathrm{O}_{3}$ are not preferable for GVL production, making [2:1] $\mathrm{Ni}-\mathrm{Cu} / \mathrm{Al}_{2} \mathrm{O}_{3}$ the most effective catalyst for this specific hydrogenation reaction. 


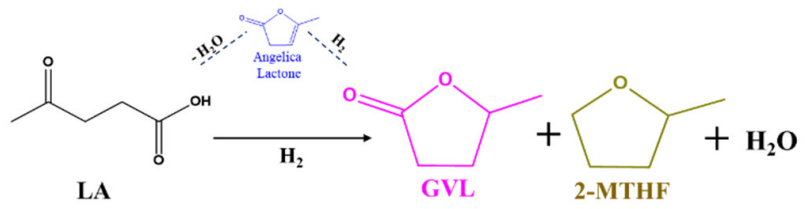

a.

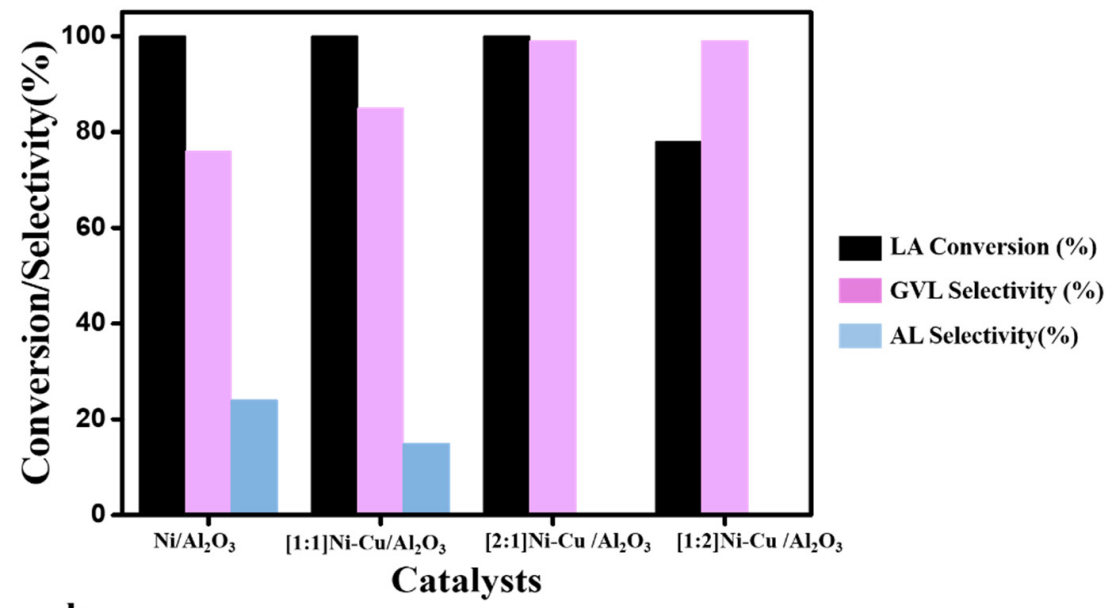

b.

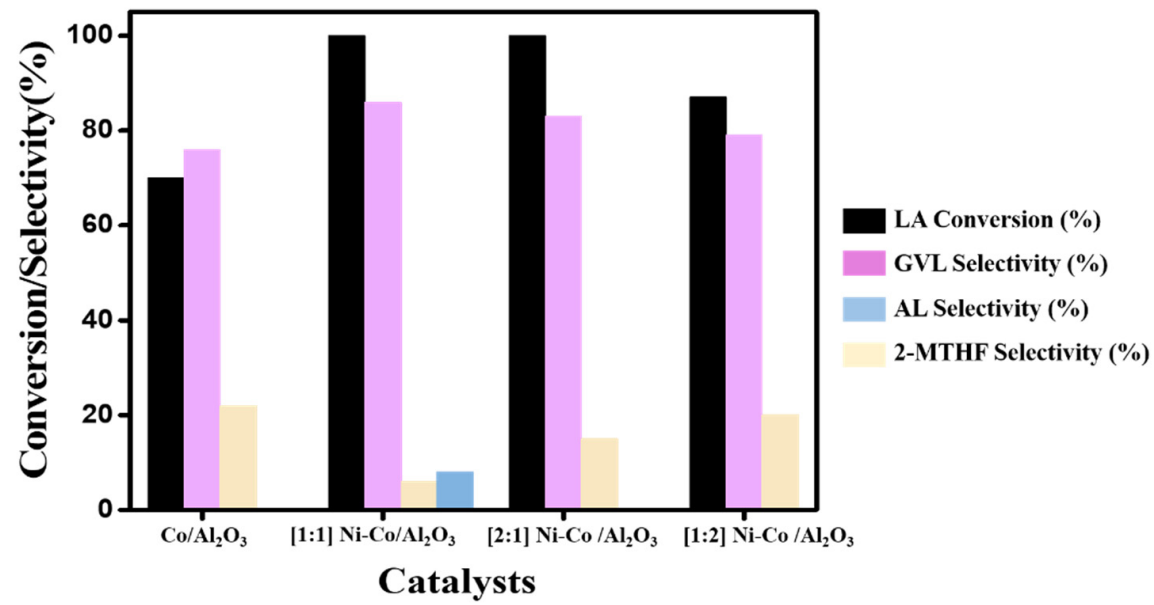

c.

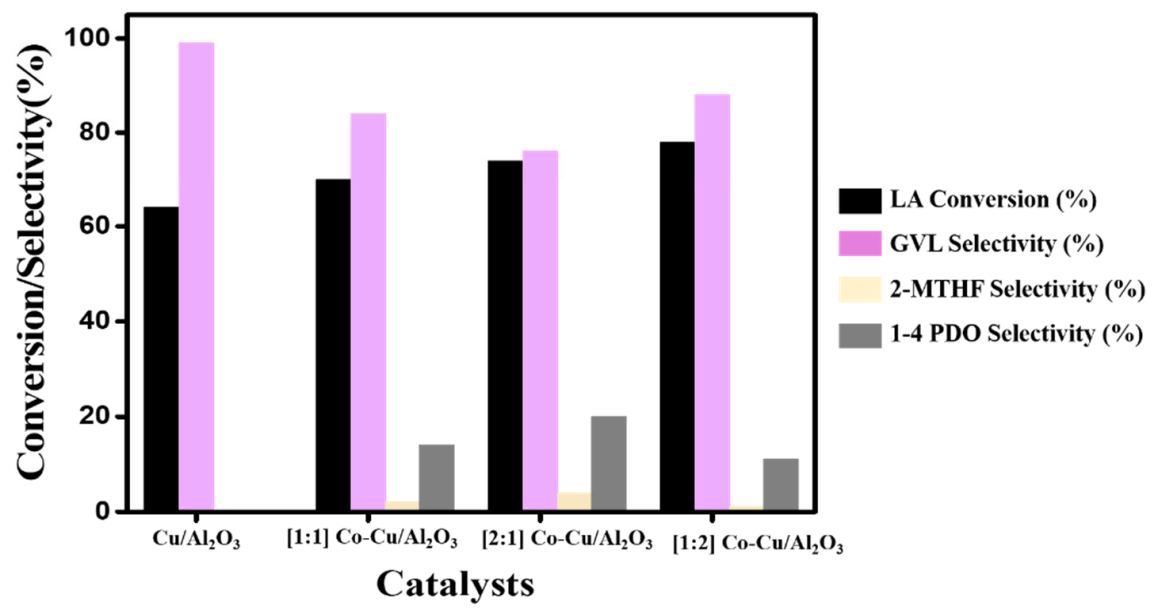

Figure 8. Levulinic acid (LA) conversion and product selectivity over (a) Ni-Cu-based catalysts, (b) Ni-Co-based catalysts, and (c) Co-Cu-based catalysts under a solvent-free condition. Reaction conditions: $20 \mathrm{~mL} \mathrm{LA}, 1 \mathrm{~g}$ catalyst, $220^{\circ} \mathrm{C}, 30$ bar $\mathrm{H}_{2}$ pressure, and A 6 h reaction time. 
The findings signify the importance of the bimetallic Ni-Cu-based catalysts in improving GVL selectivity. The balance between the metal and acid sites suitable for GVL production can be achieved through the $\mathrm{Ni} / \mathrm{Cu}$ ratio, demonstrating the role of interaction between $\mathrm{Ni}-\mathrm{Cu}$ species and the support in the catalyst system $[17,28]$.

A $71.0 \%$ conversion of LA with $76.0 \%$ and $23.0 \%$ selectivities to GVL and 2-MTHF, respectively, was achieved over $\mathrm{Co} / \mathrm{Al}_{2} \mathrm{O}_{3}$. No significant $\mathrm{AL}$ yield was obtained, indicating that all the $\mathrm{AL}$ formed was completely converted into GVL. The significant amount of 2-MTHF in the reaction mixture indicates a higher hydrogenation activity of Co towards 2-MTHF. In the case of $\mathrm{Ni}^{-} / \mathrm{Al}_{2} \mathrm{O}_{3}, \mathrm{a} \sim 24.0 \% \mathrm{AL}$ selectivity was obtained. Upon the addition of the equal weight of $\mathrm{Cu}$ and $\mathrm{Co}$, the AL selectivity was reduced to $15.0 \%$ and $8.0 \%$, respectively. The enhanced selectivities to GVL and 2-MTHF after Cu and Co addition demonstrate the respective selectivities of the secondary metal species. The improved acidity noticed in the $\mathrm{NH}_{3}$-TPD and the presence of both $\mathrm{Ni}$ and Co metal sites observed from the XPS data allow $\mathrm{Ni}-\mathrm{Co} / \mathrm{Al}_{2} \mathrm{O}_{3}$ to exhibit higher activity, increasing the conversion of the more stable GVL molecule to 2-MTHF. 2-MTHF is the result of intramolecular 1,4-PDO dehydration, which resulted from the hydrogenation of GVL. For the reaction over [1:2] Ni-Co/ $\mathrm{Al}_{2} \mathrm{O}_{3}$, a substantial decrease in the LA conversion was detected, confirming once more that $\mathrm{Ni}$ is responsible for the conversion of LA. The hydrogenation activity of the $[2: 1] \mathrm{Ni}-\mathrm{Co} / \mathrm{Al}_{2} \mathrm{O}_{3}$ catalysts was sufficient to facilitate the GVL ring-opening to 1,4-PDO. This was then followed by 1,4-PDO dehydration to 2-MTHF, which was possible due to the heightened acidic function of the [2:1] $\mathrm{Ni}-\mathrm{Co} / \mathrm{Al}_{2} \mathrm{O}_{3}$ catalyst [25]. A small amount of 2-butanol and 2-pentanol were also detected in the final reaction mixture. These findings emphasize that water, generated in situ from the hydrogenation of LA, may hinder the formation of 2-MTHF. GVL was hydrogenated to 1,4-PDO over the [2:1] $\mathrm{Ni}-\mathrm{Co} / \mathrm{Al}_{2} \mathrm{O}_{3}$ catalyst, whereas the presence of water slightly affected the dehydration of 1,4-PDO to 2-MTHF. Despite the formation of 2-butanol and 2-pentanol, the $[2: 1] \mathrm{Ni}-\mathrm{Co} / \mathrm{Al}_{2} \mathrm{O}_{3}$ catalyst shows promising results for the one-pot solvent-free production of 2-MTHF from LA [29].

The reaction result from the monometallic $\mathrm{Cu}$ catalyst showed $>99.0 \%$ selectivity to GVL with 64.0\% LA conversion, supporting the conclusion made from the bimetallic Ni-Cu catalyst regarding the potential of $\mathrm{Cu}$ in enhancing GVL selectivity. As can be seen in the deconvoluted XPS and $\mathrm{NH}_{3}$-TPD profiles, $\mathrm{Co}-\mathrm{Cu} / \mathrm{Al}_{2} \mathrm{O}_{3}$ catalysts possess a higher number of metal sites and fewer acid sites. The presence of unreacted LA in the final reaction mixture indicates that the first step of the reaction (acid-catalyzed dehydration of LA to AL) was slow. This result confirms the presence of $\mathrm{Ni}$ is critical for the conversion of LA, whereas the secondary metals are responsible for the product selectivity. No residual AL was present in the reaction mixture, implying that the hydrogenation of AL to GVL was a fast reaction due to the plentiful metal sites. On all the reactions over $\mathrm{Co}-\mathrm{Cu}$-based catalysts, there is a formation of 1,4-PDO from the hydrogenation of GVL on the metal sites, whereas only a trace amount of 2-MTHF was obtained. This phenomenon again signifies that $\mathrm{Co}-\mathrm{Cu}$-based catalysts have enough metal sites left to hydrogenate GVL to 1,4-PDO due to the higher number of metal sites, whereas not enough acid sites were left to convert 1,4-PDO to 2-MTHF. The monometallic $\mathrm{Cu} / \mathrm{Al}_{2} \mathrm{O}_{3}$ showed a lower conversion of LA with high selectivity to GVL. Upon the addition of $\mathrm{Co}$, the conversion of LA slightly increased, whereas there was a significant decrease in the selectivity to GVL due to the formation of 1,4-PDO. The change in the selectivity towards the hydrogenation products suggests that the addition of Co increased the number of active metal sites on the catalyst surface, facilitating the hydrogenation of GVL to 1,4-PDO. The absence of 1,4-PDO to 2-MTHF suggested that there are no active acid sites left for the dehydration reaction [30]. Thus, Co-Cu-based catalysts are not well suited for the hydrogenation of LA to GVL production but showed the potential to produce 1,4-PDO.

\subsubsection{Effect of Reaction Temperature}

Evidently, in the hydrogenation over [2:1] Ni-Cu/ $\mathrm{Al}_{2} \mathrm{O}_{3}$, the LA conversion increased substantially with the elevated reaction temperature up to $220^{\circ} \mathrm{C}$, whereas the GVL selectivity remained $>99.0 \%$, as shown in Figure 9. Above $220^{\circ} \mathrm{C}$, a decrease in GVL selectivity is observed, with an increased 
selectivity to AL and an exceedingly small increase in the 1,4-PDO and 2-MTHF selectivity, confirming that GVL can be hydrogenated and dehydrogenated over [2:1] $\mathrm{Ni}-\mathrm{Cu} / \mathrm{Al}_{2} \mathrm{O}_{3}$.

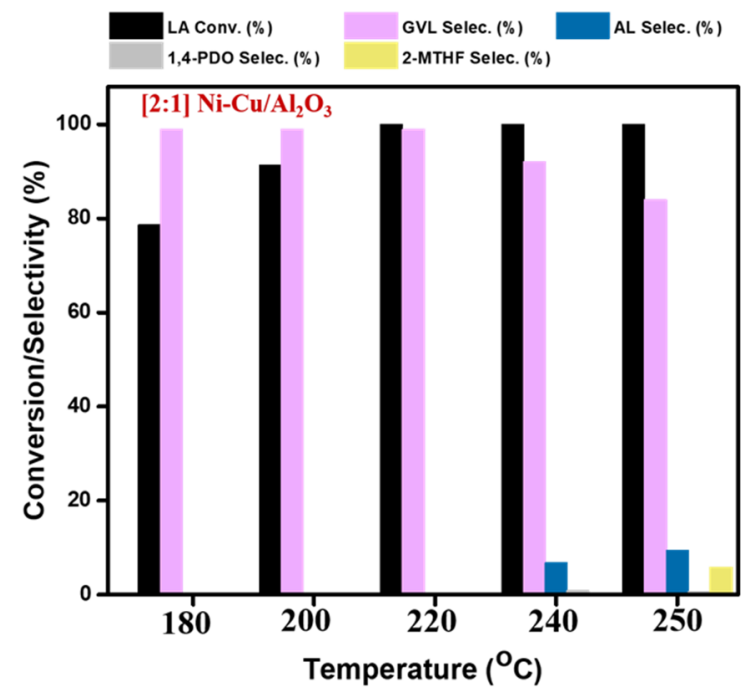

(a)

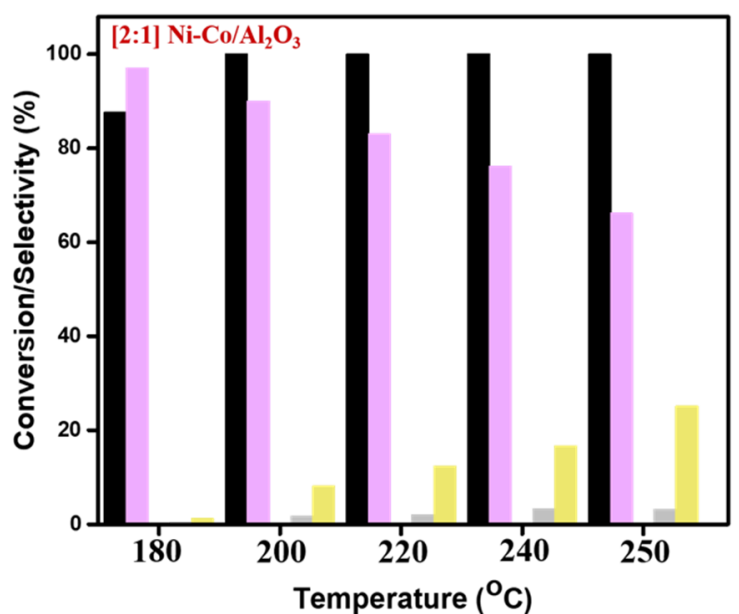

(b)

Figure 9. Reaction results for the effect of reaction temperature over (a) [2:1] Ni-Cu/ $\mathrm{Al}_{2} \mathrm{O}_{3}$ and (b) [2:1] $\mathrm{Ni}-\mathrm{Co} / \mathrm{Al}_{2} \mathrm{O}_{3}$ on the hydrogenation of LA. Reaction conditions: $20 \mathrm{~mL} \mathrm{LA}, 1 \mathrm{~g}$ catalyst, 30 bar $\mathrm{H}_{2}$ pressure and $6 \mathrm{~h}$ reaction time.

The conversion of LA to 2-MTHF is more difficult owing to the chemical stability of GVL. Thus, it requires a high reaction temperature and pressure with active metal and acid sites on a catalyst. The increased selectivity towards AL compared to 1,4-PDO suggests that the catalyst [2:1] Ni-Cu/ $\mathrm{Al}_{2} \mathrm{O}_{3}$ does not have enough active sites to catalyze the further conversion of GVL, making it ideal for the production of GVL [31]. The dehydrogenation of GVL back to AL is an unwanted reaction in the production of GVL and for the catalyst stability considering that $\mathrm{AL}$ is a typical coke precursor. A reaction temperature of $220^{\circ} \mathrm{C}$ is the most appropriate for the hydrogenation of LA to GVL [17]. Up to $90.0 \%$, GVL yield was obtained over [2:1] Ni-Co/ $\mathrm{Al}_{2} \mathrm{O}_{3}$ at a lower temperature of $200{ }^{\circ} \mathrm{C}$, indicating that the Ni-Co maintains catalyst improved metal and acid sites. Unlike the [2:1] $\mathrm{Ni}-\mathrm{Cu} / \mathrm{Al}_{2} \mathrm{O}_{3}$ catalyst, [2:1] Ni-Co/ $\mathrm{Al}_{2} \mathrm{O}_{3}$ shows a significant increase in the selectivity to 2-MTHF with the increase in temperature again confirming the characterization results. Therefore, catalysts with balanced metal sites and acid sites are required to achieve the maximum LA conversion, with high selectivity to the desired product.

\subsubsection{Effect of Reaction Pressure}

The impact of hydrogen pressure on the catalytic activity of [2:1] $\mathrm{Ni}-\mathrm{Cu} / \mathrm{Al}_{2} \mathrm{O}_{3}$ and [2:1] $\mathrm{Ni}-\mathrm{Co} / \mathrm{Al}_{2} \mathrm{O}_{3}$ was assessed, and the results are depicted in Figure 10. The $\mathrm{H}_{2}$ pressure showed a strong effect on the conversion of LA when the $\mathrm{H}_{2}$ pressure increased from 0 to 30 bar for [2:1] Ni-Cu/ $\mathrm{Al}_{2} \mathrm{O}_{3}$ and 0 to 20 bar for [2:1] Ni-Co/ $\mathrm{Al}_{2} \mathrm{O}_{3}$. Increasing the pressure above the optimum demonstrated no change in the conversion of LA, whereas the effect was prominent for the selectivity of GVL. At 30 bar, $100.0 \%$ conversion of LA and $>99.0 \%$ selectivity to GVL was obtained over [2:1] Ni-Cu/ $\mathrm{Al}_{2} \mathrm{O}_{3}$. Increasing the pressure to 40 bar resulted in a $10.0 \%$ decrease in GVL selectivity. The findings from the reaction over [2:1] Ni-Co/ $\mathrm{Al}_{2} \mathrm{O}_{3}$ imply that at lower pressure, the solubility of $\mathrm{H}_{2}$ is low, and increasing the pressure above 20 bar leads to enhanced conversion of LA. Further increasing the pressure provides a suitable reaction condition to disrupt the stable $\mathrm{C}=\mathrm{O}$ group in $\mathrm{GVL}$, leading to further ring-opening to 1,4-PDO and the subsequent cyclization to 2-MTHF. Here, again, [2:1] $\mathrm{Ni}-\mathrm{Cu} / \mathrm{Al}_{2} \mathrm{O}_{3}$-based catalysts were the most selective for the LA conversion to GVL. 


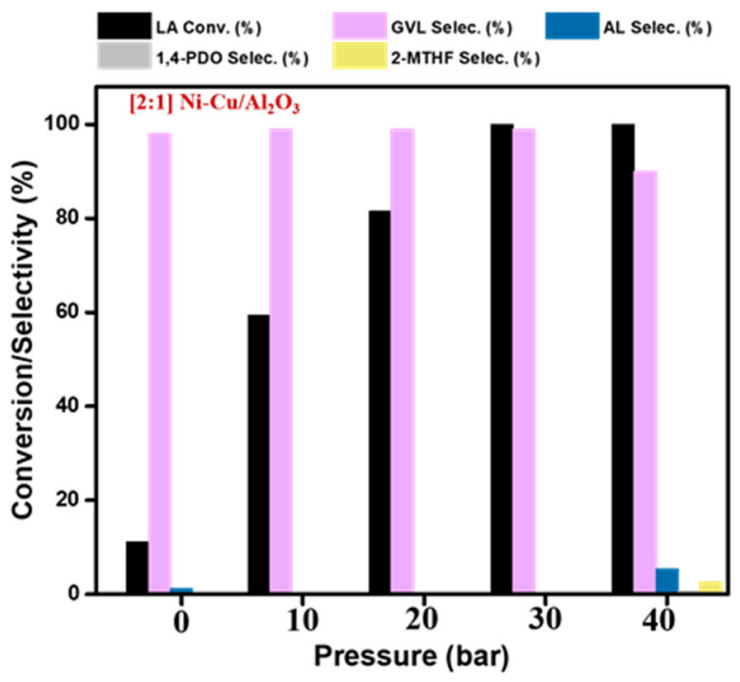

(a)

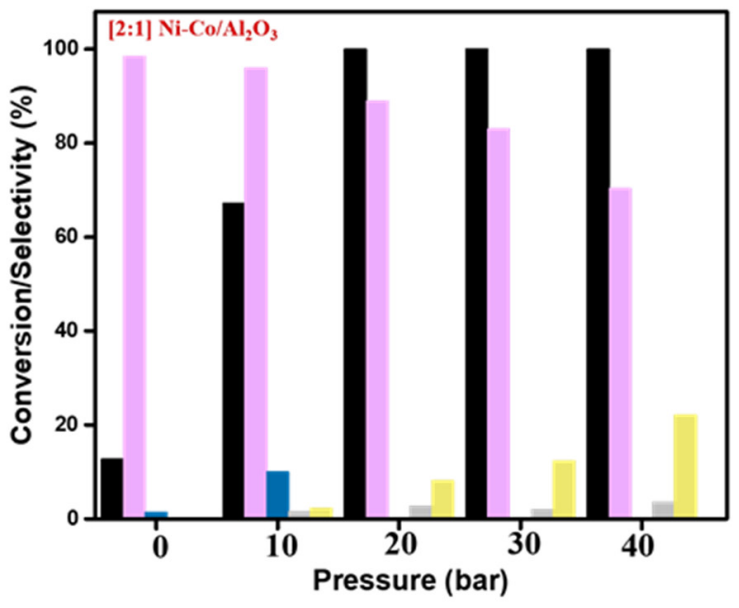

(b)

Figure 10. The reaction results for the effect of reaction pressure over $(\mathbf{a})[2: 1] \mathrm{Ni}-\mathrm{Cu} / \mathrm{Al}_{2} \mathrm{O}_{3}$ and (b) [2:1] $\mathrm{Ni}-\mathrm{Co} / \mathrm{Al}_{2} \mathrm{O}_{3}$ on the hydrogenation of LA. Reaction conditions: $20 \mathrm{~mL} \mathrm{LA}, 1 \mathrm{~g}$ catalyst, $220^{\circ} \mathrm{C}$, and $6 \mathrm{~h}$ reaction time.

\subsubsection{Effect of Reaction Time}

The effect of reaction time on the conversion of LA and selectivity to GVL was analyzed for the reactions conducted over [2:1] Ni-Cu/ $\mathrm{Al}_{2} \mathrm{O}_{3}$ and [2:1] Ni-Co/ $/ \mathrm{Al}_{2} \mathrm{O}_{3}$ to confirm the suggested reaction pathway with intermediates produced at initial reaction time and progressively, as specified in Figure 11. Over [2:1] Ni-Cu/ $\mathrm{Al}_{2} \mathrm{O}_{3}$, the conversion of LA increased rapidly, from $56.0 \%$ (2 h) to $100 \%$ $(6 \mathrm{~h})$. The conversion of LA remained constant with the increase in the reaction time to $10 \mathrm{~h}$ while the selectivity to GVL decreased. AL concentrations became significant at reaction times greater than $6 \mathrm{~h}$ after total LA conversion was attained. Thus, the identified AL is most likely produced from the synthesized GVL or by AL desorption from the [2:1] Ni-Cu/ $\mathrm{Al}_{2} \mathrm{O}_{3}$ surface. Given the results for both temperature and pressure studies, the initial option is deemed to be the reason. Only trace amounts of 2-MTHF were detected in the reaction mixture, showing that [2:1] Ni-Cu/Al $\mathrm{O}_{3}$ system is insufficient for its production. Over [2:1] Ni-Co/ $\mathrm{Al}_{2} \mathrm{O}_{3}$, the conversion of LA increased rapidly from $65.2 \%(2 \mathrm{~h})$ to $100 \%$ (6 h). Moreover, the selectivity to 2-MTHF increased at the expense of the selectivity to GVL with increased reaction time. A trace amount of 2-butanol and 2-pentanol was detected at about $8 \mathrm{~h}$ and above. This can be attributed to the effect of water released with the synthesized GVL affecting the acid sites on the [2:1] Ni-Co/Al2O3 surface required for the cyclization of 1,4-PDO. The effective formation of 2-MTHF despite the low pressure indicates that [2:1] Ni-Co/Al2O3 is a favorable catalyst for the one-pot solvent-free production of 2-MTHF from LA.

\subsubsection{Effect of Catalyst Loading}

The conversion of LA increased with the available active site up to $1.0 \mathrm{~g}$ [2:1] Ni-Cu/Al${ }_{2} \mathrm{O}_{3}$, whereas increasing the loading beyond $1.0 \mathrm{~g}$ exhibited no change in LA conversion (Figure 12). A total of $0.8 \mathrm{~g}$ catalyst loading was found to be important for the selective production of GVL over [2:1] Ni-Co/ $\mathrm{Al}_{2} \mathrm{O}_{3}$ insight of its high activity. Further increasing the catalyst loading gave $\sim 15.7 \%$ 2-MTHF. With $>99.0 \%$ GVL yield, [2:1] Ni-Cu/ $\mathrm{Al}_{2} \mathrm{O}_{3}$ is once again proving to be the best catalyst for GVL production. 

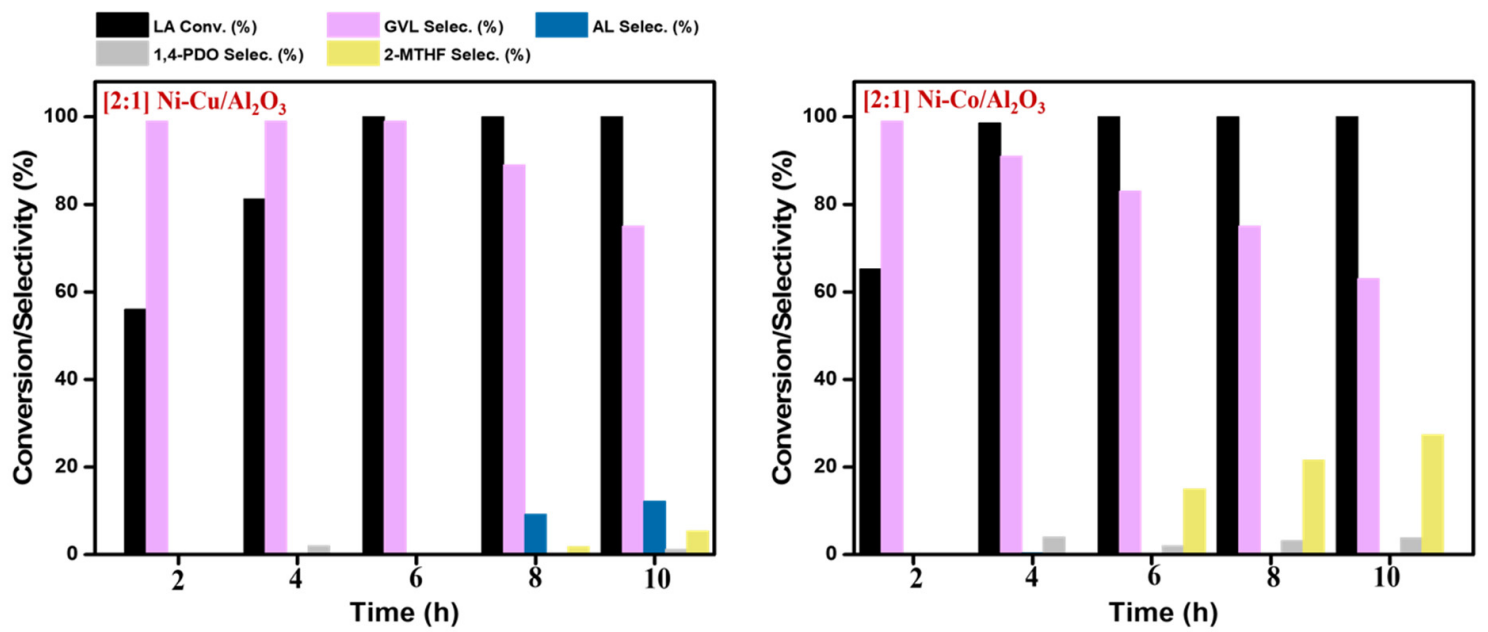

Figure 11. Reaction results for the effect of reaction time on the hydrogenation of LA. Reaction conditions: $20 \mathrm{~mL} \mathrm{LA}, 1 \mathrm{~g}$ catalyst, $220^{\circ} \mathrm{C}, 30$ bar $\mathrm{H}_{2}$ pressure.

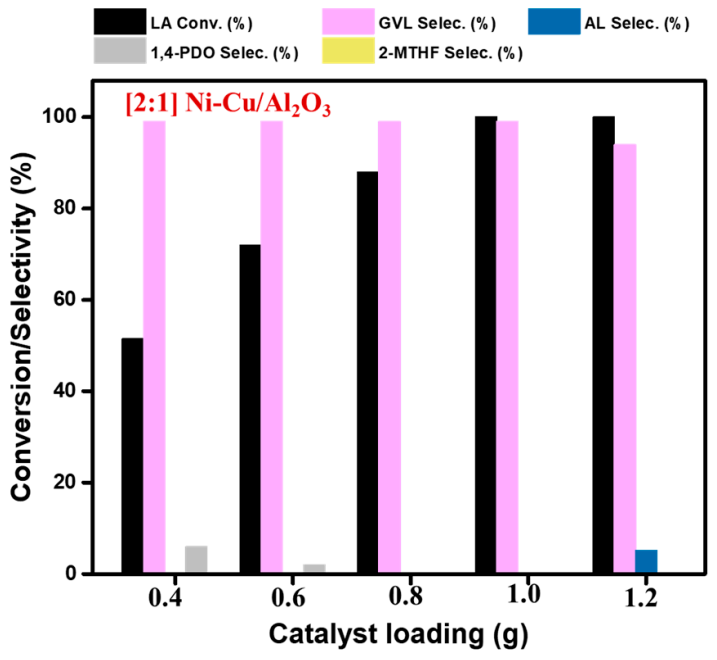

(a)

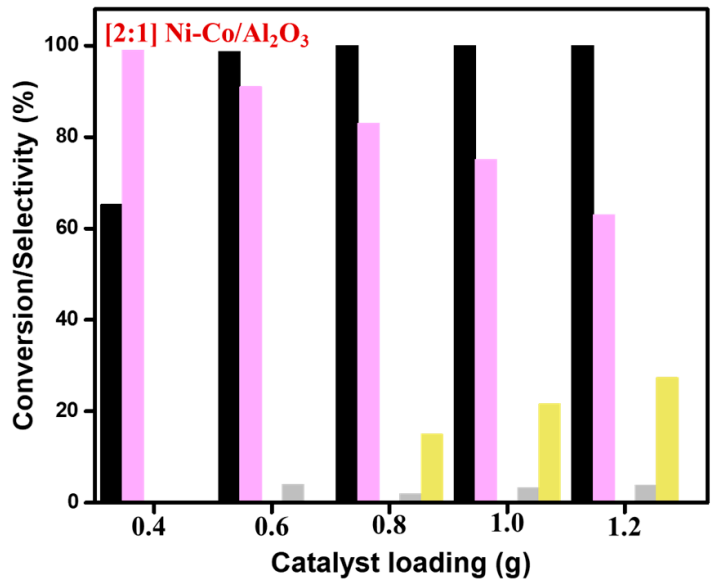

(b)

Figure 12. Reaction results for the effect of catalyst loading over (a) [2:1] $\mathrm{Ni}-\mathrm{Cu} / \mathrm{Al}_{2} \mathrm{O}_{3}$ and (b) [2:1] $\mathrm{Ni}-\mathrm{Co} / \mathrm{Al}_{2} \mathrm{O}_{3}$ on the hydrogenation of LA. Reaction conditions: $20 \mathrm{~mL} \mathrm{LA}, 220{ }^{\circ} \mathrm{C}, 30$ bar $\mathrm{H}_{2}$ pressure and $6 \mathrm{~h}$ reaction time.

\subsubsection{Metal Leaching}

Metal leaching was examined by measuring $\mathrm{Ni}, \mathrm{Cu}$, and $\mathrm{Co}$ concentrations in the reaction mixture after the reaction was completed and the result is summarized in Table S4. In general, no significant metals were found in the reaction mixture, implying negligible leaching. Ni was the least leached metal. The $\% \mathrm{Co}$ leached was low compared to $\% \mathrm{Cu}$ leached [32]. The strong interaction between $\mathrm{Co}$ and $\mathrm{Al}$ species was shown to stabilize the Co particles against leaching and sintering [33]. Results suggest that low metal leaching can be achieved if the LA conversion is $100 \%$ and no AL is present in the reaction mixture. The recyclability of $[2: 1] \mathrm{Ni}-\mathrm{Cu} / \mathrm{Al}_{2} \mathrm{O}_{3}$ was assessed through three consecutive cycles, indicating the high stability of the catalyst (Figure S3).

\subsection{Comparison with Previous Literature}

A comparison of the catalysts in this study and other previously reported catalytic systems for the solvent-free hydrogenation of LA to GVL is presented in Table 2. Most of the existing literature reported 
the high activity of Ru-based catalysts for carbonyl hydrogenation. Ru-based homogeneous catalysts also exhibited excellent catalytic performance for this reaction. However, these types of catalysts suffer from serious drawbacks concerning their homogeneity, high cost, and limited reserves. To solve these problems, transition-metal-based catalysts were developed. Nonetheless, their disadvantages involved metal leaching and catalyst recyclability, hence hindering their industrial application for GVL production.

Table 2. Comparison table with the existing catalytic systems.

\begin{tabular}{|c|c|c|c|c|c|c|}
\hline \multicolumn{7}{|c|}{ Solvent-Free Hydrogenation of LA to GVL } \\
\hline Catalysts & Temp. $\left({ }^{\circ} \mathrm{C}\right)$ & $\mathrm{H}_{2}$ Pressure (bar) & Time (h) & LA Conv. $(\%)$ & GVL Yield (\%) & Ref. \\
\hline Commercial $\mathrm{Ru} / \mathrm{C}$ & 190 & 12 & 0.75 & 100 & 100 & [29] \\
\hline Shvo catalyst (Ru-based) & 100 & 50 & 5 & 100 & 99.5 & [34] \\
\hline $\mathrm{Ru} / \mathrm{FLG}$ & 37 & 40 & 58 & 100 & 93.5 & [35] \\
\hline Pyrazolylphosphite and & & & & & & \\
\hline $\begin{array}{l}\text { Pyrazolylphosphinite Ru } \\
\text { (II) complexes }\end{array}$ & 110 & 15 & 12 & 100 & 100 & [36] \\
\hline $\mathrm{Co} / \mathrm{SiO}_{2}$ & 200 & 30 & $10(20)$ & 100 & $80(98)$ & [25] \\
\hline $\mathrm{Ni} / \mathrm{Al}_{2} \mathrm{O}_{3}$ & 200 & 50 & 4 & 92 & 92 & [37] \\
\hline$[2: 1] \mathrm{Ni}-\mathrm{Co} / \mathrm{Al}_{2} \mathrm{O}_{3}$ & 220 & 30 & 6 & 100 & 83 & This work \\
\hline$[2: 1] \mathrm{Ni}-\mathrm{Cu} / \mathrm{Al}_{2} \mathrm{O}_{3}$ & 220 & 30 & 6 & 100 & $>99$ & This work \\
\hline
\end{tabular}

\section{Experimental}

\subsection{Materials}

Levulinic acid (LA) was purchased from Acros Organics, Fair Lawn, NI, USA. For the support and catalyst synthesis, aluminum isopropoxide $\left(\mathrm{C}_{9} \mathrm{H}_{21} \mathrm{AlO}_{3}\right)$ and the metal nitrates $\mathrm{Ni}\left(\mathrm{NO}_{3}\right)_{2} \cdot 6 \mathrm{H}_{2} \mathrm{O}$, $\mathrm{Cu}\left(\mathrm{NO}_{3}\right) \cdot 3 \mathrm{H}_{2} \mathrm{O}$, and $\mathrm{Co}\left(\mathrm{NO}_{3}\right)_{2} \cdot 6 \mathrm{H}_{2} \mathrm{O}$ were procured from Sigma Aldrich St. Louis, $\mathrm{MO}$, USA. The purchased chemicals were used without further purifications.

\subsection{Methods}

\subsubsection{Catalyst Synthesis}

Preparation of $\gamma-\mathrm{Al}_{2} \mathrm{O}_{3}$ Nanofibers

$\gamma-\mathrm{Al}_{2} \mathrm{O}_{3}$ nanofibers were synthesized according to a formerly reported procedure $[38,39]$ with some modifications. In a typical synthesis of $\gamma-\mathrm{Al}_{2} \mathrm{O}_{3}$ nanofibers $50 \mathrm{~g}$ aluminum, isopropoxide was dissolved in $300 \mathrm{~mL}$ isopropyl alcohol at $80{ }^{\circ} \mathrm{C}$ for $2 \mathrm{~h}$. A $40 \mathrm{~mL}$ volume of $0.28 \mathrm{M}$ acetic acid was added dropwise, and the solution refluxed for $4 \mathrm{~h}$ under stirring. The following solution was then moved to a Teflon-lined stainless-steel reactor and heated in an oven at $120^{\circ} \mathrm{C}$ for $24 \mathrm{~h}$. The solid obtained after filtration was washed multiple times with deionized water and ethanol and dried at $110{ }^{\circ} \mathrm{C}$ overnight. Subsequent calcination at $600^{\circ} \mathrm{C}$ for $5 \mathrm{~h}$ in air with a ramping rate of $2{ }^{\circ} \mathrm{C} / \mathrm{min}$ resulted in $\gamma-\mathrm{Al}_{2} \mathrm{O}_{3}$ nanofibers.

\section{Catalyst Preparation}

The catalysts were synthesized by the incipient impregnation method. In a typical preparation of $35 \mathrm{wt} . \% \mathrm{Ni}-\mathrm{Cu} / \mathrm{Al}_{2} \mathrm{O}_{3}$ catalyst, an aqueous solution containing the calculated amounts of the required metal precursors $\left(\mathrm{Ni}\left(\mathrm{NO}_{3}\right)_{2} \cdot 6 \mathrm{H}_{2} \mathrm{O}\right.$ and $\left.\mathrm{Cu}\left(\mathrm{NO}_{3}\right) 3 \mathrm{H}_{2} \mathrm{O}\right)$ with the desired ratio of metals was firstly impregnated on the as-synthesized $\gamma-\mathrm{Al}_{2} \mathrm{O}_{3}$ fibers. This mixture was vigorously stirred for $12 \mathrm{~h}$ and subsequently dried at $110{ }^{\circ} \mathrm{C}$ overnight. The resulting powder was calcined in static air at $500{ }^{\circ} \mathrm{C}$ for $4 \mathrm{~h}$. For the $\mathrm{H}_{2}$ reduction, the catalyst was subjected to a $10 \% \mathrm{H}_{2} / \mathrm{Ar}$ gas flow at $500{ }^{\circ} \mathrm{C}$ for $2 \mathrm{~h}$ at a ramping rate of $10^{\circ} \mathrm{C} / \mathrm{min}$ in a tube furnace. The Ni-Co and $\mathrm{Cu}$-Co-based catalysts were also prepared with this procedure but with the use of their corresponding metal nitrates. 


\subsubsection{Catalyst Characterization}

To evaluate the textural properties (surface area, pore volume, and pore size) of the catalysts, the nitrogen physical adsorption-desorption method was performed using the BELSORP-miniII instrument (Bel Japan Inc., Osaka, Japan). Before the analysis, the catalysts were degassed in a vacuum at $110^{\circ} \mathrm{C}$ for $4 \mathrm{~h}$. To study the crystallinity, X-ray diffraction (XRD) measurements, in the $2 \theta$ range of $20^{\circ}$ to $80^{\circ}$, were performed using a Rigaku D-Max2500-PC diffractometer (Rigaku International Corporation, Tokyo, Japan). To investigate the morphology, transmission electron microscopy (TEM) was conducted in a JEOL JEM-3011HR microscope (JEOL GmbH, Freising, Germany). The samples were prepared by sonicating a small amount of the catalysts in ethanol and depositing it onto a JEM-3011HR microscope. To examine the elemental composition, X-ray photoelectron spectroscopy (XPS) was performed using XPS Thermo, Esc lab 250 xi (Thermo Fisher Scientific, Waltham, MA, USA). To investigate the reducibility and acidity of the catalysts, hydrogen temperature-programmed reduction $\left(\mathrm{H}_{2}\right.$-TPR) and ammonia temperature-programmed desorption $\left(\mathrm{NH}_{3}-\mathrm{TPD}\right)$ were performed, respectively. For the pretreatment of the catalysts for both $\mathrm{H}_{2}-\mathrm{TPR}$ and $\mathrm{NH}_{3}-\mathrm{TPD}$, the samples were subjected to $50 \mathrm{~mL} / \mathrm{min}$ helium flow at $100{ }^{\circ} \mathrm{C}$ for $2 \mathrm{~h}$. The $\mathrm{H}_{2}$-TPR profiles of the calcined samples were recorded in the range of $100-800{ }^{\circ} \mathrm{C}$ at a heating rate of $10{ }^{\circ} \mathrm{C} / \mathrm{min}$ under a $10 \% \mathrm{H}_{2} / \mathrm{Ar}$ gas flow. The consumption of hydrogen was monitored using a thermal conductivity detector (TCD). For $\mathrm{NH}_{3}$-TPD, the reduced samples were subjected to a $50 \mathrm{~mL} / \mathrm{min}$ flow of $5 \% \mathrm{NH}_{3} / \mathrm{He}$ to adsorb the ammonia. For the desorption of the ammonia, the furnace temperature was increased from 100 to $800{ }^{\circ} \mathrm{C}$ at a heating rate of $5^{\circ} \mathrm{C} / \mathrm{min}$ under a helium flow of $30 \mathrm{~mL} / \mathrm{min}$. The elemental contents of the catalysts and metal leaching were determined by inductively coupled plasma optical emission spectroscopy (ICP-OES) iCAP 7400DUO (Thermo Fisher Scientific, Waltham, MA, USA). The catalysts $(20 \mathrm{mg})$ were digested in aquaria $\left(\mathrm{HNO}_{3}: \mathrm{HCl} ; 1: 3\right)$ for $2 \mathrm{~h}$ and diluted to $25 \mathrm{~mL}$ by distilled water.

\subsubsection{Activity Tests}

\section{Hydrogenation of Levulinic Acid}

The solvent-free hydrogenation of LA to GVL was conducted in a $100 \mathrm{~mL}$ stainless steel (SUS $316 \mathrm{~L}$ ) high-pressure batch reactor. In a representative reaction run, $20 \mathrm{~mL}$ of LA and $1 \mathrm{~g}$ of catalyst were loaded into the reactor. The reactor was then sealed and initially purged three times with argon gas to eliminate traces of $\mathrm{O}_{2}$ and air before pressurizing it with $\mathrm{H}_{2}$ gas to the desired reaction pressure. After reaching the desired pressure, the reactor was heated up to the set temperature. The start of the reaction was the time when the target temperature was attained. After the reaction, the reactor was cooled to room temperature, and the catalyst was separated from the reaction mixture through filtration.

\section{Product Qualification and Quantification}

For the quantification of the products, the purified product was analyzed in Waters High-Performance Liquid Chromatography (Milford, MA, USA) equipped with an Agilent Hi-Plex C-6 column $(7.7 \mathrm{~mm} \times 300 \mathrm{~mm} \times 8 \mu \mathrm{m})$ and a refractive index detector (Santa Clara, CA, USA). A $5 \mu \mathrm{m}$ $\mathrm{H}_{2} \mathrm{SO}_{4}$ solution was used as the mobile phase. The conversion of $L A$ and selectivity towards $G V L$ were calculated using the following equations:

$$
\begin{aligned}
& \text { LA conversion }(\%)=\frac{L A \text { in feed }-L A \text { in effluent }}{L A \text { in feed }} \times 100 \% \\
& G V L \text { selectivity }(\%)=\frac{G V L \text { in effluent }}{L A \text { in feed }-L A \text { in effluent }} \times 100 \%
\end{aligned}
$$

\section{Conclusions}

Monometallic $\mathrm{Ni}, \mathrm{Cu}, \mathrm{Co}$, and bimetallic $\mathrm{Ni}-\mathrm{Cu}, \mathrm{Ni}-\mathrm{Co}$, and $\mathrm{Co}-\mathrm{Cu}$ catalysts supported on $\gamma-\mathrm{Al}_{2} \mathrm{O}_{3}$ nanofibers were synthesized by the incipient impregnation method and applied for the solvent-free 
hydrogenation of $\mathrm{LA}$ to GVL. The $\gamma-\mathrm{Al}_{2} \mathrm{O}_{3}$ nanofiber support was found to be important as the reaction between metal precursor and $\mathrm{OH}$ group on the surface of the $\gamma-\mathrm{Al}_{2} \mathrm{O}_{3}$ nanofiber results in a strong metal-support interaction, providing additional Lewis acid sites, as confirmed by the $\mathrm{NH}_{3}$-TPD. Of the examined metals, Ni was the most active metal for LA conversion, but its selectivity to GVL was found to be deficient. Co has lower conversion with the lowest selectivity to GVL, whereas $\mathrm{Cu}$ has the lowest conversion with the highest selectivity to GVL. These results suggest that the monometallic catalysts need improvement to achieve both high conversion and selectivity. The bimetallic catalysts showed improved activity and selectivity. The high activity of the bimetallic catalysts can be attributed to the cooperative effect between $\mathrm{M}_{1}-\mathrm{M}_{2}$ species yielding both metal and acid sites responsible for the conversion of LA to AL and the conversion of AL to GVL, respectively. It was shown that a suitable $\mathrm{Ni} / \mathrm{Cu}, \mathrm{Ni} / \mathrm{Co}$, and $\mathrm{Co} / \mathrm{Cu}$ ratio was valuable to improve the conversion of LA and the selectivity to GVL in the solvent-free hydrogenation by enhancing the balance between metal and acid sites on the surface of the bimetallic catalysts. In all metal combinations, a 2:1 $\mathrm{M}_{1} / \mathrm{M}_{2}$ ratio was found to be ideal. Values of $>99.0 \%, \sim 83.0 \%$, and $\sim 65.0 \%$ GVL yield were obtained over [2:1] Ni-Cu/ $\mathrm{Al}_{2} \mathrm{O}_{3}$, [2:1] Ni-Co/ $\mathrm{Al}_{2} \mathrm{O}_{3}$, and [2:1] Co-Cu/ $\mathrm{Al}_{2} \mathrm{O}_{3}$, respectively. [2:1] $\mathrm{Ni}-\mathrm{Co} / \mathrm{Al}_{2} \mathrm{O}_{3}$, and [2:1] $\mathrm{Co}-\mathrm{Cu} / \mathrm{Al}_{2} \mathrm{O}_{3}$ showed promising selectivities to 2-MTHF and 1,4-PDO, correspondingly. These findings provide a new perspective in the solvent-free hydrogenation of LA, with new possibilities for applications in the solvent-free production of 1,4-PDO and 2-MTHF.

Supplementary Materials: The following are available online at http:/www.mdpi.com/2073-4344/10/11/1354/ s1, Figure S1: The XRD diffraction diagrams of the bimetallic catalysts at a different metal ratio, Figure S2: TEM images of selected catalysts at $500 \mathrm{~nm}$ and $50 \mathrm{~nm}$, Figure S3: The recyclability test over [2:1] Ni-Cu/Al2O3. Reaction conditions: $20 \mathrm{~mL}$ LA, $1 \mathrm{~g}$ catalyst, $220^{\circ} \mathrm{C}, 30$ bar H2 pressure and $6 \mathrm{~h}$ reaction time. Table S1: List of the synthesized catalysts, Table S2: The textural properties of the bimetallic catalysts at a different metal ratio, and Table S3: Metal leaching analysis

Author Contributions: M.N.G.: Conceptualization, methodology, investigation, data curation, writing-original draft preparation. R.Q.R.: conceptualization, investigation, writing一original draft preparation. H.K.: supervision, validation. J.G.S.: visualization, supervision, writing - reviewing and editing, validation. All authors have read and agreed to the published version of the manuscript.

Funding: This work was supported by the Energy Efficiency and Resources Program (No. 20183030092080) of the Korea Institute of Energy Technology Evaluation and Planning (KETEP) grant funded by the Korea government Ministry of Trade, Industry and Energy. This work was supported by the National Research Foundation of Korea (NRF) grant funded by the Korea government (MSIT) (No. 2020R1A5A1019131).

Conflicts of Interest: The authors declare no conflict of interest.

\section{References}

1. Alonso, D.M.; Bond, J.Q.; Dumesic, J.A. Catalytic conversion of biomass to biofuels. Green Chem. 2010, 12, 1493-1513. [CrossRef]

2. Isikgor, F.H.; Becer, C.R. Lignocellulosic biomass: A sustainable platform for the production of bio-based chemicals and polymers. Polym Chem. 2015, 6, 4497-4559. [CrossRef]

3. Bozell, J.; Petersen, G.R. Technology development for the production of biobased products from biorefinery carbohydrates-the US Department of Energy's “top 10" revisited. Green Chem. 2010, 12, 539-555. [CrossRef]

4. Pileidis, F.D.; Titirici, M. Levulinic Acid Biorefineries: New Challenges for Efficient Utilization of Biomass. ChemSusChem 2016, 9, 562-582. [CrossRef] [PubMed]

5. Dutta, S.; Yu, I.K.M.; Tsang, D.C.W.; Ng, Y.H.; Ok, Y.S.; Sherwood, J.; Clark, J.H. Green synthesis of gamma-valerolactone (GVL) through hydrogenation of biomass-derived levulinic acid using non-noble metal catalysts: A critical review. Chem. Eng. J. 2019, 372, 992-1006. [CrossRef]

6. Horvath, I.T.; Mehdi, H.; Fabos, V.; Boda, L.; Mika, L.T. $\gamma$-Valerolactone - a sustainable liquid for energy and carbon-based chemicals. Green Chem. 2008, 10, 238-242. [CrossRef]

7. Abdelrahman, O.A.; Heyden, A.; Bond, J.Q. Analysis of kinetics and reaction pathways in the aqueous-phase hydrogenation of levulinic acid to form $\gamma$-Valerolactone over Ru/C. ACS Catal. 2014, 4, 1171-1181. [CrossRef]

8. Yan, Z.; Lin, L.; Liu, S. Synthesis of $\gamma$-Valerolactone by Hydrogenation of Biomass-derived Levulinic Acid over Ru/C Catalyst. Energy Fuels 2009, 23, 3853-3858. [CrossRef] 
9. Upare, P.P.; Lee, J.M.; Hwang, D.W.; Halligudi, S.B.; Hwang, Y.K.; Chang, J.S. Selective hydrogenation of levulinic acid to $\gamma$-valerolactone over carbon-supported noble metal catalysts. J. Ind. Eng. Chem. 2011, 17, 287-292. [CrossRef]

10. Putro, J.N.; Kurniawan, A.; Soetaredjo, F.E.; Lin, S.S.; Ju, Y.; Ismadji, S. Production of gamma-valerolactone from and acid-activated bentonite as a co-catalyst. RSC Adv. 2015, 5, 41285-41299. [CrossRef]

11. Yan, K.; Lafleur, T.; Jarvis, C.; Wu, G. Clean and selective production of $\gamma$-valerolactone from biomass-derived levulinic acid catalyzed by recyclable Pd nanoparticle catalyst. J. Clean. Prod. 2014, 72, 230-232. [CrossRef]

12. Amarasekara, A.S.; Hasan, M.A. Pd/C catalyzed conversion of levulinic acid to $\gamma$-valerolactone using alcohol as a hydrogen donor under microwave conditions. CATCOM 2015, 60, 5-7. [CrossRef]

13. Gupta, S.S.R.; Kantam, M.L. Selective hydrogenation of levulinic acid into $\gamma$-valerolactone over $\mathrm{Cu} / \mathrm{Ni}$ hydrotalcite-derived catalyst. Catal. Today 2018, 309, 189-194. [CrossRef]

14. Obregón, I.; Corro, E.; Izquierdo, U.; Requies, J.; Arias, P.L. Levulinic acid hydrogenolysis on $\mathrm{Al}_{2} \mathrm{O}_{3}$-based Ni-Cu bimetallic catalysts. Chin. J. Catal. 2014, 35, 656-662. [CrossRef]

15. Sun, D.; Ohkubo, A.; Asami, K.; Katori, T.; Yamada, Y.; Sato, S. Vapor-phase hydrogenation of levulinic acid and methyl levulinate to $\gamma$-valerolactone over non-noble metal-based catalysts. Mol. Catal. 2017, 437, $105-113$. [CrossRef]

16. Long, X.; Sun, P.; Li, Z.; Lang, R.; Xia, C.; Li, F. Magnetic $\mathrm{Co} / \mathrm{Al}_{2} \mathrm{O}_{3}$ catalyst derived from hydrotalcite for hydrogenation of levulinic acid to $\gamma$-valerolactone. Chin. J. Catal. 2015, 36, 1512-1518. [CrossRef]

17. Liu, M.; Li, S.; Fan, G.; Yang, L.; Li, F. Hierarchical Flower-like Bimetallic NiCu catalysts for Catalytic Transfer Hydrogenation of Ethyl Levulinate into $\gamma$-Valerolactone. Ind Eng. Chem Res. 2019, 58, 10317-10327. [CrossRef]

18. Torres, D.; Pinilla, J.L.; Suelves, I. Co-, Cu-and Fe-doped $\mathrm{Ni} / \mathrm{Al}_{2} \mathrm{O}_{3}$ catalysts for the catalytic decomposition of methane into hydrogen and carbon nanofibers. Catalysts 2018, 8, 300. [CrossRef]

19. Sharifi, M.; Haghighi, M.; Rahmani, F.; Rahemi, N. Reforming of Biogas over Co- and Cu-Promoted $\mathrm{Ni} / \mathrm{Al}_{2} \mathrm{O}_{3}-\mathrm{ZrO}_{2}$ Nanocatalyst Synthesized via Sequential Impregnation Method. J. Renew. Energy Environ. 2014, 1, 53-63.

20. Xue, H.; Xu, J.; Gong, X.; Hu, R. Performance of a Ni-Cu-Co/ $\mathrm{Al}_{2} \mathrm{O}_{3}$ Catalyst on in-situ Hydrodeoxygenation of Bio-derived Phenol. Catalysts 2019, 9, 952. [CrossRef]

21. Shejale, A.D.; Yadav, G.D. Ni-Cu and Ni-Co Supported on La-Mg Based Metal Oxides Prepared by Coprecipitation and Impregnation for Superior Hydrogen Production via Steam Reforming of Glycerol. Ind. Eng. Chem. Res. 2018, 57, 4785-4797. [CrossRef]

22. Wang, Y.; Chen, M.; Yang, Z.; Liang, T.; Liu, S.; Zhou, Z.; Li, X. Bimetallic Ni-M (M=Co, Cu, and Zn) supported on attapulgite as catalysts for hydrogen production from glycerol steam reforming. Appl. Catal. A Gen. 2018, 550, 214-227. [CrossRef]

23. You, X.; Wang, X.; Ma, Y.; Liu, J.; Liu, W.; Xu, X.; Peng, H.; Li, C.; Zhou, W.; Yuan, P.; et al. Ni-Co/Al $\mathrm{Al}_{2}$ Bimetallic Catalysts for $\mathrm{CH}_{4}$ Steam Reforming: Elucidating the Role of Co for Improving Coke Resistance. ChemCatChem 2014, 6, 3377-3386. [CrossRef]

24. Srivastava, S.; Jadeja, G.C.; Parikh, J. A versatile bi-metallic copper-cobalt catalyst for liquid-phase hydrogenation of furfural to 2-methylfuran. RSC Adv. 2016, 6, 1649. [CrossRef]

25. Novodárszki, G.; Solt, H.E.; Valyon, J.; Lónyi, F.; Hancsók, J.; Deka, D.; Tuba, R.; Mihalyi, M.R. Selective hydroconversion of levulinic acid to $\gamma$-valerolactone or 2-methyltetrahydrofuran over silica-supported cobalt catalysts. Catal. Sci. Technol. 2019, 9, 2291-2304.

26. Xue, Z.; Liu, Q.; Wang, J.; Mu, T. Valorization of levulinic acid over non-noble metal catalysts: Challenges and opportunities. Green Chem. 2018, 20, 4391-4408. [CrossRef]

27. Yu, Z.; Meng, F.; Wang, Y.; Sun, Z.; Liu, Y.; Shi, C.; Wang, W.; Wang, A. Catalytic Transfer Hydrogenation of Levulinic Acid to $\gamma$-Valerolactone over $\mathrm{Ni}_{3} \mathrm{P}-\mathrm{CePO}_{4}$ Catalysts. Ind. Eng. Chem. Res. 2020, 59, 7416-7425. [CrossRef]

28. Sun, D.; Takahashi, Y.; Yamada, Y.; Sato, S. Efficient formation of angelica lactones in a vapor-phase conversion of levulinic acid. Appl. Catal. A Gen. 2016, 526, 62-69. [CrossRef]

29. Al-Shaal, M.G.; Dzierbinski, A.; Palkovits, R. Solvent-free $\gamma$-valerolactone hydrogenation to 2methyltetrahydrofuran catalyzed by $\mathrm{Ru} / \mathrm{C}$ : A reaction network analysis. Green Chem. 2014, 16, 1358-1364. [CrossRef] 
30. Wu, J.; Gao, G.; Sun, P.; Long, X.; Li, F. Synergetic Catalysis of Bimetallic CuCo Nanocomposites for Selective Hydrogenation of Bio derived Esters. ACS Catal. 2017, 7, 7890-7901. [CrossRef]

31. Obregon, I.; Gandarias, I.; Mileti, N.; Ocio, A.; Arias, P.L. One-Pot 2-Methyltetrahydrofuran Production from Levulinic Acid in Green Solvents Using Ni-Cu/Al $\mathrm{O}_{3}$ Catalysts. ChemSusChem 2015, 8, 3483-3488. [CrossRef] [PubMed]

32. Zhang, L.; Mao, J.; Li, S.; Yin, J.; Sun, X.; Guo, X.; Song, C.; Zhou, J. Hydrogenation of levulinic acid into gamma-valerolactone over in situ reduced $\mathrm{CuAg}$ bimetallic catalyst: Strategy and mechanism of preventing Cu leaching. Appl. Catal. B Environ. 2018, 232,1-10. [CrossRef]

33. Srivastava, S.; Jadeja, G.C.; Parikh, J. Copper-cobalt catalyzed liquid phase hydrogenation of furfural to 2-methylfuran: An optimization, kinetics, and reaction mechanism study. Chem. Eng. Res. Des. 2018, 132, 313-324. [CrossRef]

34. Van Slagmaat, C.A.M.R.; Delgove, M.A.F.; Stouten, J.; Morick, L.; Van Der Meer, Y.; Bernaerts, K.V.; De Wildeman, S.M.A. Solvent-free hydrogenation of levulinic acid to $\gamma$-valerolactone using a Shvo catalyst precursor: Optimization, thermodynamic insights, and life cycle assessment. Green Chem. 2020, 22, 2443-2458. [CrossRef]

35. Xiao, C.; Goh, T.W.; Qi, Z.; Goes, S.; Brashler, K.; Perez, C.; Huang, W. Conversion of Levulinic Acid to $\gamma$-Valerolactone over Few-Layer Graphene-Supported Ruthenium Catalysts. ACS Catal. 2016, 6, 593-599. [CrossRef]

36. Amenuvor, G.; Makhubela, B.C.E.; Darkwa, J. Efficient solvent-free hydrogenation of levulinic acid to $\gamma$-valerolactone by pyrazolylphosphite and pyrazolylphosphinite ruthenium (II) complexes. ACS Sustain. Chem. Eng. 2016, 4, 6010-6018. [CrossRef]

37. Hengst, K.; Schubert, M.; Carvalho, H.W.P.; Lu, C.; Kleist, W.; Grunwaldt, J.D. Synthesis of $\gamma$-valerolactone by hydrogenation of levulinic acid over supported nickel catalysts. Appl. Catal. A Gen. 2015, 502, 18-26. [CrossRef]

38. Liu, C.; Hong, J.; Zhang, Y.; Zhao, Y.; Wang, L.; Wei, L.; Chen, S.; Wang, G.; Li, J. Synthesis of $\gamma-\mathrm{Al}_{2} \mathrm{O}_{3}$ nanofibers stabilized $\mathrm{Co}_{3} \mathrm{O}_{4}$ nanoparticles as highly active and stable Fischer-Tropsch synthesis catalysts. Fuel 2016, 180, 777-784. [CrossRef]

39. Jiao, H.; Zhao, X.; Lv, C.; Wang, Y.; Yang, D.; Li, Z.; Yao, X. $\mathrm{Nb}_{2} \mathrm{O}_{5}-\gamma-\mathrm{Al}_{2} \mathrm{O}_{3}$ nanofibers as heterogeneous catalysts for efficient conversion of glucose to 5-hydroxymethylfurfural. Sci. Rep. 2016, 6, 1-9. [CrossRef]

Publisher's Note: MDPI stays neutral with regard to jurisdictional claims in published maps and institutional affiliations.

(C) 2020 by the authors. Licensee MDPI, Basel, Switzerland. This article is an open access article distributed under the terms and conditions of the Creative Commons Attribution (CC BY) license (http://creativecommons.org/licenses/by/4.0/). 